\title{
Allometric Models to Estimate Carbon Content in Arecaceae Based on Seven Species of Neotropical Palms
}

\section{Milena Cambronero}

School for Field Studies

Gerardo Avalos ( $\nabla$ faetornis@yahoo.com )

University of Costa Rica School of Biology: Universidad de Costa Rica Escuela de Biologia https://orcid.org/0000-0003-2663-4565

Carolina Alvarez-Vergnani

University of Costa Rica School of Biology: Universidad de Costa Rica Escuela de Biologia

\section{Research Article}

Keywords: carbon stocks, carbon sequestration, allometric models

Posted Date: September 13th, 2021

DOl: https://doi.org/10.21203/rs.3.rs-838582/v1

License: (c) (1) This work is licensed under a Creative Commons Attribution 4.0 International License. Read Full License 
$4 \quad$ Milena Cambronero² (milemd4@yahoo.com)

5 Gerardo Avalos ${ }^{1,2}$ (gerardo.avalos@ucr.ac.cr)

6 Carolina Alvarez-Vergnani ${ }^{1}$ (caroav@gmail.com)

7

$8 \quad{ }^{1}$ Escuela de Biología, Universidad de Costa Rica, 11501-2060 San Pedro, San José, Costa

9 Rica

10

11

12

13

14

15

16

17

18

19

20

21

22

23

24

\section{neotropical palms}

Allometric models to estimate carbon content in Arecaceae based on seven species of Rica

${ }^{2}$ The School for Field Studies, Center for Sustainable Development Studies, 100 Cummings Center, Suite 534G, Beverly, MA 01915, USA.

2

Correspondence: Gerardo Avalos, gerardo.avalos@ucr.ac.cr, (506) 25115955
Author Contributions: GA conceived and designed the experiments. MC and CAV conducted the fieldwork with assistance from GA. GA, MC, and CAV analyzed the data and wrote the manuscript.

1

2




\section{Abstract}

We present allometric models to estimate total carbon content and above ground carbon (AGC) for the family Arecaceae, and for 7 abundant neotropical palm species (the canopy species Socratea exorrhiza and Iriartea deltoidea, the sub-canopy palm Euterpe precatoria, and the understory species Asterogyne martiana, Prestoea decurrens, Geonoma interrupta and Chamaedorea tepejilote). The study was done in the tropical rainforests of the Caribbean slope of Costa Rica. We harvested 87 individuals of a wide range of sizes, and divided them into roots, stems, and leaves, weight their fresh and dry biomass, calculated the carbon content, tissue density, leaf area, and shoot:root ratios (based on biomass and carbon content). The general palm model estimating total carbon content accounted for $92 \%$ of the variation and had diameter at breast height, stem height, and dry mass fraction as predictor variables. We generated a similar model to estimate AGC, which included the same variables and explained $91 \%$ of the variation. We compared our AGC model with two models used to estimate palm carbon content: Goldman et al. (2013)'s and Chave et al. (2014)'s models and found a range of $\mathrm{R}^{2}$ values of 0.87 to 0.91 . Understory palm allometry was centered around biomass allocation, whereas sub-canopy and canopy species were associated with traits related to palm size (mainly DBH, total height, and leaf area). The efficiency the allometric models depends on species identity, sample size, and size range.

Keywords: carbon stocks, carbon sequestration, allometric models

\section{Introduction}

Over the last century, land-use changes, logging, forest fires, and burning of fossil fuels have caused a dramatic increase in the atmospheric concentration of carbon dioxide 
$49\left(\mathrm{CO}_{2}\right)$, as well as of other greenhouse gases $(\mathrm{GHG})$, leading to severe climate events (Clark

50 2007; Díaz et al. 2019). Accurate models to estimate carbon stocks are critical to

51 successfully implement carbon and climate change policies (Zhang et al. 2012; Chave et al.

52 2014). Numerous organizations, including the United Nations Framework Convention on

53 Climate Change (UNFCCC), have warned of the urgency of reducing GHG emissions and

54 mitigating the effects of climate change to maintain the viability of ecosystems and keep

55 suitable conditions for human life. To achieve these goals, it is essential to elucidate the

56 behavior of various carbon sinks and sources to understand the consequences of

57 anthropogenic effects on the climate (Clark 2007; Houghton 2007; Canadell and Raupach

58 2008; Goers et al. 2012; Steffen et al. 2018).

59 Tropical forests influence the atmospheric concentration of $\mathrm{CO}_{2}$, are important

60 reservoirs of carbon, and play a significant role in mitigating the effects of climate change

61 (Houghton 2007; Goers et al. 2012) but are becoming net carbon sources as their capacity

62 to absorb and store carbon is diminished by logging, land-use changes, droughts, and forest

63 fires (Brando et al. 2019; Friedlingstein et al. 2020). It is still necessary to refine

64 methodologies to quantify carbon sequestration in tropical forests, as well as to increase the

65 available information across plant groups to understand how different species, ontogenetic

66 stages, and life forms contribute to the total accumulation of carbon in terrestrial

67 ecosystems (Dewar 1991; Dewar and Cannell 1992; Brown 1997; Achard et al. 2004).

68 Currently, there are numerous methods to estimate the carbon stocks in forested areas

69 (Zhang et al. 2012). Remote sensing techniques facilitate the monitoring of extensive areas

70 with low costs and large-scale resolution (Jucker et al. 2017; Rodríguez-Veiga et al. 2019)

71 but are limited by field validation using ground-based techniques. Allometric methods

72 represent a traditional, but time-consuming alternative. These methods are based on 
mathematical models relating morphological measurements to biomass or stored carbon (Hairiah et al. 2001; Chave et al. 2005, 2014; Montero and Montagnini 2005; Zhang et al. 2012) and have some extensive databases (Chave et al. 2005; Curtis 2008; Lal 2008;

Lorenz and Lal 2010, Kissling et al. 2019). Most allometric studies have focused on woody dicotyledonous trees, particularly the most common and commercially important species (Brown 1997; Hairiah et al. 2001; Chave et al. 2005; Zhang et al. 2012; Chave et al. 2014), and usually include only a handful of individuals of a limited size range per species. Life forms such as lianas, hemiepiphytes, ferns, and palms have been excluded from these inventories (Clark et al. 2001; Chave et al. 2005, 2014; Jucker et al. 2017). Few studies (Nascimento and Laurance 2002; Lima et al. 2012) have included a variety of life forms, like palms and lianas.

Palms (Arecaceae) are one of the most diverse and widely distributed groups of plants in tropical and subtropical areas, with around 2,600 species and 181 genera (Baker and Dransfield 2016). Many tropical ecosystems are dominated by palms (Mejia and Kahn 1990; Myers 2013), such as seasonally or permanently inundated wetlands, such as the "aguajales" in the Peruvian Amazon (dominated by Mauritia flexuosa, Sampaio et al. 2008), the "yolillales" in Costa Rica (dominated by Raphia taedigera, Serrano-Sandí et al. 2013; Yaap et al. 2015), and peatlands in tropical swamp forests in the Congo basin (some dominated by $R$. laurentii and $R$. hookeri), which are important reservoirs of soil carbon (Lähteenoja et al. 2009; Dargie et al. 2017). Due to their abundance in the Amazon lowlands, palms have been considered "hyperdominant" elements (ter Steege et al. 2013), with 6 out of the 10 most abundant species being palms. Although they have a limited contribution to carbon stocks in diverse tropical rainforests (Fauset et. 2015), palms can influence forest function (Boukili and Chazdon 2017), play a crucial role in food webs, 
97 providing habitat and food to a multitude of animal species (Zona and Henderson 1989;

98 Howard et al. 2001; Onstein et al. 2017), and are invaluable to many human groups who

99

100

101

102

103

104

105

106

107

108

109

110

111

112

113

114

115

116

117

118

119

120 use them as raw materials for construction, food, drink, clothing, fuel, medicine, and fibers

(Jones 1995; Henderson 2002; Dransfield et al. 2008; Sylvester et al. 2012)

Despite their functional role, palms have been excluded from most inventories of

carbon accumulation in tropical forests (DeWalt and Chave 2004; Chave et al. 2005;

Lorenz and Lal 2010), as well as from comprehensive allometric analysis of diameter vs.

height relationships (Feldpausch et al. 2011). The few studies on carbon content in palms

are limited to the wetland species M. flexuosa and M. aculeata (Goodman et al. 2013), and

commercially important species, such as peach palm, Bactris gasipaes (Ares et al. 2002),

and oil palm, Elaeis guineensis (Thenkabail et al. 2004; Syahrinudin 2005; Leblanc et al.

2006; Ekadinata et al. 2010; Khasanah et al. 2012; Pulhin et al. 2014). As monocots, palms

have a different structure, allometry, and strategies of resource use relative to trees

(Tomlinson 2006, 2011). With a few exceptions, palms are monopodial and lack aerial

branching, have only one shoot meristem, and lack dormancy and secondary growth. In

palm species where stem diameter and stem height show a significant relationship, diameter increases through sustained primary growth (i.e., through the division, lignification, and

expansion of parenchyma cells, which also differentiate into fibers, Tomlinson 2011). In

addition, leaf longevity and leaf construction costs are higher in palms than in

dicotyledonous trees (Renninger and Phillips 2016), which have smaller leaves than palms

and could drop leaflets rather than the entire frond to acclimate to new light conditions.

Palm responses to environmental gradients are fundamentally different from those of

woody plants. It is essential to understand their allometric relationships to develop accurate and more specific models to estimate their contribution to carbon storage. 
122 carbon storage in seven species of neotropical palms from different forest strata, b) to

123 produce general models to estimate above-ground carbon and total carbon for palms based

124 on these species using traits commonly measured in forest inventories, and c) compare 125 these models with two of the most widely used models to estimate the contribution of 126 palms to carbon storage: the Goodman et. (2013)'s model, developed for a subset of 8 127 species of neotropical palms, and the pantropical model of Chave et al. (2014), developed 128 for dicotyledonous trees. These specific palm models may have similar limitations to the 129 models generated for dicotyledonous trees, are biased by the species composition, the 130 number and size of the harvested individuals, and the environmental conditions of the 131 collection sites. Despite these limitations, the generation of specific models for palms is 132 necessary as the lack of data for this group makes it difficult to estimate their contribution 133 to the carbon balance of tropical forests, especially in habitats where palms are very 134 abundant.

We expected that the diameter at breast height $(\mathrm{DBH})$ and stem height would be the 136 best predictors of carbon storage, since it has been shown that both variables are related to 137 biomass accumulation (Goodman et al. 2013), are functionally related to carbon storage, 138 determine mechanical support (Avalos et al. 2019), and reflect palm size. We did not 139 expect wood density (or the density of the sclerotized tissue in palms) to be an important 140 predictor of carbon content, since palms do not develop wood, but rather have a sclerotized 141 tissue that is not evenly distributed along the stem, and which increases in density and 142 mechanical strength from the base and the periphery of the stem towards the crown (Rich 143 1986; Henderson 2002). Finally, we expected that the use of Chave et al. (2014)'s model, 144 developed for trees, would lead to an underestimation of carbon storage in palms, due to the 
145 significant structural and allometric differences between dicotyledonous trees and palms, 146 and the inclusion of tissue density in Chave et al. (2014)'s model.

147

148 Materials and methods

150 Study site

151 Palms were harvested in three tropical rain forest sites in the Caribbean lowlands of Costa 152 Rica. The first two were La Selva Biological Station (10²6’N - 835’ W, 30-150 masl, 153 annual precipitation 4,162 $\mathrm{mm})$ and Tirimbina Biological Reserve $\left(10^{\circ} 24^{\prime} \mathrm{N}-84^{\circ} 06 \mathrm{~W}\right.$, 154 180-220 masl, annual precipitation 3,833 mm), both situated in Sarapiquí, Heredia. The 155 third site was the lowland forest of the agroecological farm El Progreso $\left(10^{\circ} 30^{\prime} 35^{\prime \prime}\right.$ N $15683^{\circ} 44^{\prime} 39^{\prime}$ ' W, 45 masl, annual precipitation of 4,000 to 5,000 mm), located in Pococí, 157 Limón. The three sites present an average daily temperature of $25^{\circ} \mathrm{C}$ and have a weak 158 climatic seasonality, with November, December and February being the rainiest months 159 (McDade et al. 1994).

161 Study species

162 We selected seven palm species belonging to different forest strata (Table 1). The canopy 163 species Socratea exorrhiza (S Nicaragua to Brazil, 0-750 masl) and Iriartea deltoidea (SE 164 Nicaragua to Brazil, 0-800 masl) can reach 25 and $30 \mathrm{~m}$ of stem height, respectively, and 165 are characteristic canopy components of mature forests (Grayum 2003). Both species have 166 a cone of stilt roots, although roots in I. deltoidea are clustered at the base of the stem and 167 grow up to $1.5 \mathrm{~m}$ above ground, and in $S$. exorrhiza roots are well-separated, covered by 168 spines, and can grow up to $4 \mathrm{~m}$ above the ground (Henderson et al. 1995). The subcanopy 
species Euterpe precatoria (Belize to Bolivia, 0-1150 masl) var longevaginata (Henderson 1995) is single-stemmed and can reach $26 \mathrm{~m}$ in height, developing a stilt root cone that in extreme cases may reach over $2 \mathrm{~m}$ in height (Avalos and Schneider 2011). Understory species included Prestoea decurrens, Chamaedorea tepejilote, Geonoma interrupta and Asterogyne martiana. Prestoea decurrens (Nicaragua to Ecuador, 0-900 masl), is a clonal species reaching $10 \mathrm{~m}$ in height (Grayum 2003). Chamaedorea tepejilote (S Mexico to Colombia, 0-1600 masl) is a dioecious species which can grow up to $5 \mathrm{~m}$ (Grayum 2003, Castillo-Mont et al. 1994). Geonoma interrupta (S Mexico to Peru, 0-850 masl) has a solitary stem and may reach $6 \mathrm{~m}$ in height (and over $10 \mathrm{~m}$ in exceptional cases), being considered as one of the tallest species in the genus (Grayum 2003). Finally, Asterogyne martiana (Belize to Ecuador, 0-1,000 masl) is an understory species with a decumbent stem often reaching $2 \mathrm{~m}$ in height, and with simple, bifid leaves.

\section{Palm harvesting, morphological measurements, and biomass estimation}

From Sept-2013 to May-2015, we harvested 87 palms, representing the full range of size classes observed in the field (Table 1). We measured stem diameter at $1.3 \mathrm{~m}$ above the ground, at half the stem length in palms less than $1.3 \mathrm{~m}$ in height, or immediately above the stilt roots in palms with a stilt root cone higher than $1.3 \mathrm{~m}$, and called this measurement in all cases, DBH. Harvested palms were separated into modules (stems, roots, and leaves) and we measured the total fresh biomass of each module using a Pesola ${ }^{\circledR}$ Macro-Line Spring Scale $(30 \pm 0.25 \mathrm{~kg})$. We dug out the roots carefully, collected all the root material to the extent that was possible, including fine roots ( $5 \mathrm{~mm}$ in diameter). In instances in which it was difficult to extract all the roots, due to their size or depth, a representative section was extracted, and from this, we estimated the total root biomass. We washed out 
193

194

195

196

197

198

199

200

201

202

203

204

205

206

207

208

209

210

211

212

213

214 in a test tube, sealed, and transferred back to the laboratory for the estimation of tissue

215 density.

the roots in the field and sun-dried them before weighing them in the laboratory. To determine the dry biomass (and carbon content) we collected $300 \mathrm{mg}$ samples from each module. For leaves this sample included one young, one intermediate, and one mature frond, determined according to their position from the tip of the apical meristem. In stems, the biomass sample was collected from the base, middle, and upper part of the stem until reaching the base of the leaf crown. The total height of the palm $\left(\mathrm{H}_{\mathrm{tot}}\right)$ was measured from ground level to the base of the crown, including the height of the cone of stilt roots (if present), or as the total length of the stem (from the point of connection with the roots to the base of the petiole of the youngest leaf), including the section of the subterranean stem in A. martiana. This measurement is more practical for forest inventories, since in a complex forest it is difficult to observe the very top of the apical meristem within a dense palm crown and a dense forest canopy. The height of the stem to the base of the crown $\left(\mathrm{H}_{\mathrm{bc}}\right)$ was estimated as the length of the aerial stem (from the top of the root cone if present, that is, the base of the stem) to the insertion of the oldest leaf, which corresponds to the base of the crown. This measurement was recorded for stilt rooted species (S. exorrhiza, I. deltoidea, E. precatoria, and P. decurrens). Finally, to estimate the tissue density of the stem (specific gravity, $\rho$ ), we used a Haglof 2-Thread Increment Borer, to collect a tissue sample from the stem, following the methods of Chave et al. (2005). Accordingly, we selected a point of entry for the increment borer near the base of the stem, in the middle, and near the base of the palm crown to place the borer at the center of the internode and carry out the perforation. Once the sclerotized tissue was extracted, the sample was placed 


\section{Estimation of carbon content and stem tissue density}

We dried the samples in an oven at $65^{\circ} \mathrm{C}$ for $48 \mathrm{~h}$ or until constant weight. Once dried, we ground the samples and determined their carbon content using an automatic analyzer TruSpec CN, LECO Corporation, at the Laboratory of the Department of Systematic Botany at the University of Ulm, Germany, and an automatic elemental carbon and nitrogen analyzer, VarioMacrocube, at the University of Costa Rica. The magnitude of the carbon content in $\mathrm{g}$ was calculated by multiplying the total dry weight of each module by the percentage of carbon obtained in the laboratory and adding up all the dry biomass per individual palm. The average carbon fraction for the palms analyzed here was $43.9 \% \pm 1.28$ (Cambronero et al. 2018), but for our models we used the average carbon fraction obtained for each species. Stem tissue density (specific gravity, $\rho$ ) was calculated as the ratio of dry biomass $(\mathrm{g})$ over volume $\left(\mathrm{cm}^{3}\right)$. Volume was measured by water displacement.

\section{Estimation of total leaf area per palm}

To determine the total leaf area, we followed the methods of Avalos and Sylvester (2010).

The three collected leaves (one young, one intermediate, and one mature), were cleaned with a dry cloth and the leaf area was measured with a LICOR LI-3100 C leaf area meter (LICOR, Lincoln, NE, USA). From these measurements we estimated the total leaf area per individual palm by averaging the leaf area of the three leaves and multiplying it by the total number of fronds. This parameter was not used to predict carbon accumulation since measuring leaf area is difficult in forest inventories. However, we included it in the principal component analysis to examine palm morphological variation across species. 
241 The generation of allometric models aims to provide practical options for applying them in

242 studies of forest carbon inventories. We proposed models including a combination of

243 variables that are commonly measured under field conditions, such as DBH and stem

244 height. We included stem tissue density to explore the importance of this parameter in

245 palms, although its measurement requires access to instrumentation that might not be

246 readily available in the field. To predict carbon content, we calculated linear and

247 logarithmic stepwise regressions between the natural logarithm of the total amount of

248 carbon content in $\mathrm{kg}$ per palm ( $\mathrm{LN}(\mathrm{C})$, response variable), and a set of explanatory

249 variables including $\mathrm{DBH}(\mathrm{cm})$, total stem height from the base of the stem to the base of the

250 leaf crown $\left(\mathrm{H}_{\mathrm{tot}}, \mathrm{m}\right.$, including stilt roots if present), the height of the stem to the base of the

251 crown $\left(\mathrm{H}_{\mathrm{bc}}, \mathrm{m}\right.$, excluding stilt roots if present), the dry mass fraction (dry mass over fresh

252 mass, dmf), and stem tissue density $\left(\mathrm{g} \mathrm{cm}^{-3}\right)$. The predictor variables were included in the

253 models with their ln-transformed values as well as in their linear scales. We carried out the

254 stepwise regression analysis for each species, and then selected the most parsimonious

255 general regression model for all seven species based on the magnitudes of the $\mathrm{R}^{2}$ value, the

256 mean square of error (MSE), and the Akaike Information Criterion (AIC). Since the

257 response variable required a logarithmic transformation, a correction factor was calculated,

258 according to Sprugel (1983). We used R software for all statistical analyses. In cases where

259 a higher fit of the model was justified, we combined two or more predictor variables.

Estimation of above-ground carbon content in palms: comparing a pantropical tree

263 We estimated the aboveground carbon content (AGC in $\mathrm{kg}$ ) by adding the carbon content

264 fractions of stems and leaves without considering the carbon content of roots to compare 
our model with those of Goodman et al. (2013) and Chave et al. (2014), which consider only above ground biomass (AGB). Goodman et al. (2013)'s model estimates AGB for 8 species of neotropical palms, including E. precatoria, I. deltoidea and S. exorrhiza, examined here, using $\mathrm{AGB}^{0.25}=\left(\mathrm{dmfD}^{2} \mathrm{H}_{\text {stem }}\right)^{0.25}$, where $\mathrm{dmf}$ is the dry mass fraction defined above, $\mathrm{D}$ is $\mathrm{DBH}$, and $\mathrm{H}_{\text {stem }}$ is the height of the palm from the ground to the highest leaf. To determine AGC, we applied the conversion factor of $50 \%$ of the dry biomass, which has traditionally been used to determine the carbon accumulated in trees (Chave et al. 2005; Houghton 2007; Lorenz and Lal 2010). The pantropical model of Chave et al. (2014) estimates AGB using $0.0673\left(\rho \mathrm{D}^{2} \mathrm{H}\right)^{0.976}$, where $\rho$ corresponds to wood stem density ( $\mathrm{g} \mathrm{cm}^{-3}$, or tissue density for palms), $\mathrm{D}$ is the $\mathrm{DBH}(\mathrm{cm})$, and $\mathrm{H}$ is the total height $(\mathrm{m})$; this model is based on data from 4,004 trees $\geq 5 \mathrm{~cm}$. AGC was then calculated by applying the carbon fraction of 50\% to AGB as in the case of Goodman et al. (2013)'s model. We did not include other models developed for palms such as the one by Brown (1997), or by Frangi and Lugo (1985), since these had lower performance and lower $\mathrm{R}^{2}$ values when applied to our data ( 0.78 and 0.79 , respectively).

We used the actual carbon fraction per palm species measured directly here (Cambronero et al. 2018) for the comparison with Goodman et al. (2013) and Chave et al. (2014) models. In both cases, the accuracy of all models was contrasted against the observed values of AGC using the $\mathrm{R}^{2}$ value and the magnitude of their residuals. We used natural logarithmic models for the comparisons.

\section{Root:shoot ratios}

We calculated root:shoot ratios as the dry biomass of roots over the dry biomass of aboveground parts (stems and leaves). This corresponds to the root:shoot ratio of dry biomass. In 
addition, we obtained the root:shoot ratio of the carbon fraction after calculating the carbon

289 fraction of the above-ground and below-ground biomass.

\section{Analysis of the correlation structure of morphological characters in our subset of palms}

292 We analyzed interspecific variation in key individual morphological traits related to

293 biomass allocation and tissue quality: tissue density, dmf, slenderness ratio (total stem

294 height over DBH), and root:shoot ratios (calculated based on the dry biomass, and carbon

295 content levels). We measured the phenotypic variation in morphological characters using

296 the ln-transformation of DBH, stem height, number of leaves, tissue density, dmf, leaf area,

297 slenderness ratio, root:shoot ratio (at the biomass and carbon content level), and total stored

298 carbon through principal component analysis, and used the scores of the first two

299 components to inspect the distribution of all the species in the multidimensional space

300 defined by correlation structure of morphological characters.

301

302 Results

303 Palms across species showed a wide range of sizes, reflecting the variation observed in the 304 field, where size and biomass increased from understory to canopy species (Table 1).

305 Average tissue density differed among canopy and subcanopy species (lower values) vs.

306 understory species (higher values, $\mathrm{F}_{6,80}=8.44, \mathrm{P}<0.0001$ ). Tissue density decreased from

307 canopy to understory species, but understory species showed higher variation (Figure 1A).

308 Differences in tissue density were significant among species (2-way ANOVA, F $2,221=$

$30962.86, \mathrm{p}<0.0001)$, and position along the stem $\left(\mathrm{F}_{6,221}=3.94, \mathrm{p}=0.02\right)$. Even though tissue

310 density varied with position in the stem (Figure 2), the magnitude of the differences was 
311 small within a species. Therefore, we used the average value of tissue density as a predictor 312 of carbon content in our models.

313 There were significant differences in slenderness ratio across species $\left(\mathrm{F}_{6,80}=6.95, \mathrm{P}\right.$

$314<0.0001)$. Differences were not associated with strata, but were centered among species,

315 with E. precatoria, P. decurrens and G. interrupta showing the highest values (Figure 1B).

316 The dmf ratio also showed significant differences among species $\left(\mathrm{F}_{6.80}=16.2, \mathrm{P}<0.001\right.$,

317 Figure 1C). Here, differences followed the strata, with understory species showing highest

318 dmf values. Root:shoot ratios measured at the dry biomass level also showed significant

319 differences among species $\left(\mathrm{F}_{6,80}=4.92, \mathrm{P}=0.0002\right.$, Figure 1D), with $S$. exorrhiza and $A$.

320 martiana showing the highest values. The same pattern was found when the analysis was

321 done for root:shoot ratios based on carbon content $\left(\mathrm{F}_{6,80}=5.25, \mathrm{P}=0.0001\right.$, Figure $\left.1 \mathrm{E}\right)$.

322 Here, S. exorrhiza diverged from the rest, which had small differences in this parameter

323 across species.

324

325

Species-level allometric models to estimate total carbon content.

326 Canopy and subcanopy species

327 In S. exorrhiza the most parsimonious model for predicting total carbon content had the

328 linear form of DBH. Entering other variables in the model (total height and stem height 329 from the base, in linear and logarithmic forms -in addition to $\operatorname{Ln}(\mathrm{DBH})-$ ), produced similar

$330 \mathrm{R}^{2}$ values but not a lower AIC (Table 2). For I. deltoidea, the most parsimonious models

331 included DBH and total height, both in its logarithmic and linear forms. For the subcanopy

332 palm, E. precatoria, the most parsimonious models had total height, height from the base of

333 the stem, and DBH (linear and logarithmic), with the linear form of total height as the best-

334 fit model. In none of the canopy and subcanopy species, tissue density and dmf had a 
significant effect on carbon content (Table 2). In this set of species, $\mathrm{R}^{2}$ values from significant regressions were high and ranged from 0.79 to 0.97 . Models combining two or more predictor variables produced a fit comparable to the highest value of $\mathrm{R}^{2}$ of singlevariable models. Models combining two or more variables were not considered as optimal since it was not justified to increase model complexity without a significant change in the fit of the model.

\section{Understory species}

Understory species showed a lower fit relative to canopy and subcanopy species, with $\mathrm{R}^{2}$ values ranging from 0.28 to 0.95 . For $C$. tepejilote, we did not find differences in the morphological parameters among male and female plants, and thus, the analyses were done for the overall species. The best-fit model included the logarithmic form of total height and DBH. For P. decurrens, the logarithmic forms of height from the base of the stem and total height were the most parsimonious models, with similar $\mathrm{R}^{2}$ values $(0.85-0.87)$ for models with one variable. The combined model for $P$. decurrens included the ln-transformations of $\mathrm{DBH}$, total height, and tissue density, with an $\mathrm{R}^{2}$ value of 0.95 . For $A$. martiana, the most efficient models had DBH as the best predictor variable, both in its linear and logarithmic forms. The most parsimonious model in this species, however, had the logarithmic forms of DBH and tissue density. Finally, G. interrupta showed the highest fit for models including total height (logarithmic and linear, with a $\mathrm{R}^{2}$ of 0.92 and 0.91 , respectively) as the most parsimonious. In this species, DBH did not influence carbon content. Prestoea decurrens and $G$. interrupta were the species for which tissue density had a significant effect on carbon content (Table 2). Dry mass fraction had a significant effect on carbon storage only in G. interrupta. 
360 Family-level model to estimate total carbon content and above-ground carbon content

361 The total height and DBH (both in linear and logarithmic forms) generated the models with

362 low AIC values to estimate total carbon content at the family level $(\operatorname{Ln}(\mathrm{C})$, Table 3). To

363 these variables, we added dmf to generate a general natural logarithmic model explaining

$36492 \%$ of the variation in stored carbon across species; this model had the lowest AIC value

365 (Table 3). The models that were significant and included a single variable ranged in $\mathrm{R}^{2}$

366 values from $0.66(\mathrm{DBH})$ to $0.80\left(\mathrm{Ln} \mathrm{H}_{\mathrm{tot}}\right.$ and linear $\left.\mathrm{H}_{\mathrm{tot}}\right)$. Tissue density was not significant.

367 The variable dmf had a significant effect although the amount of variation explained in total 368 carbon content was low.

369 We followed a similar procedure to estimate AGC (Table 4). The most

370 parsimonious model (highest $\mathrm{R}^{2}, 0.91$, and lowest AIC, -107.05) had the logarithmic

371 transformation of $\mathrm{DBH}$, total height, and dmf as predictors of $\mathrm{Ln}$ (AGC).

372 We then compared the most parsimonious model of Table 4 with the palm model of

373 Goodman et al. (2013) and the pantropical model proposed by Chave et al. (2014) for

374 dicotyledonous trees (Figure 3) using Ln (AGC). All three models predicted the observed

375 Ln (AGC) with high $\mathrm{R}^{2}$ values ranging from 0.879-0.911. Our model had the highest $\mathrm{R}^{2}$

376 value (0.911) followed by Chave et al. (2014) with 0.882, and then Goodman et al. (2013)'s

377 with 0.879. Chave et al. (2014)'s model showed the highest residual variation, and

378 Goodman et al. (2013) the lowest. We consider all three models to be sufficiently efficient

379 to predict the AGC of the palm species analyzed here.

380

$381 \quad$ Principal component analysis 
382

383

384

385 386

401
The correlation matrix of morphological characters showed higher and positive correlation coefficients among variables related to palm size, such as $\mathrm{DBH}, \mathrm{H}_{\mathrm{tot}}$, total carbon content, and leaf area. Variables related to structural characteristics, such as slenderness ratio, tissue density, and root:shoot ratios, had low correlation coefficients (Figure 4). The variable dmf showed intermediate correlation values.

We defined three principal components explaining $77.87 \%$ of the variation in the data. The first component $(44.4 \%)$ had a similar weight of $\mathrm{DBH}$, height, and total carbon content, which were variables related to palm size. The second component $(17.74 \%)$ had a similar contribution of tissue density and slenderness ratio. The third component $(15.73 \%)$ had a similar contribution of root:shoot ratios, both based on total dry biomass and carbon content (Table 5).

The distribution of species in the multidimensional space defined by the first two principal components showed that understory species were more related to palm structure and biomass distribution (tissue density, slenderness ratio and dmf), whereas subcanopy and canopy species were more associated with characters related to palm size (DBH, stem height, leaf area, total carbon content), as well as root:shoot ratios (Figure 5). Understory species showed more spread of the data reflecting the high structural diversity found in this group.

\section{Discussion}

The contribution of palms to overall forest biomass in neotropical rainforests is small. On Barro Colorado Island, palms represented 0.43\% of AGC (50-ha plot census from 1982, pers. obs.). At the Luquillo tropical rainforest in Puerto Rico, which is dominated by Prestoea montana, palms contribute $10.9 \%$ of the biomass (Frangi and Lugo 
1985 ) and $32 \%$ of the fallen leaves. In the tropical rainforest of La Selva Biological Station in Costa Rica, palms represented $5.4 \%$ of AGB, although they make up $25 \%$ of stems $\geq 10$ cm DBH (Clark and Clark 2000). In Manaus, Brazil, stemless palms contributed $0.3 \%$ of AGB (Nascimento and Laurance 2002). In a tropical rainforest, also in Manaus, palm biomass represented, on average, less than $1 \%$ of the living AGB, although in some plots they contributed 10\% (de Castilho et al. 2006). In the upper Rio Negro basin, palms make up 2.8\% of AGB (Lima et al. 2012). In wetlands, palms may constitute a larger percentage of AGB since in these environments they are often the dominant group and are established on soils storing large amounts of carbon (Lähteenoja et al. 2009). Although palms make up a small percentage of the carbon stock of neotropical rainforests, they are functionally important (Boukili and Chazdon 2017), intervening in nutrient cycling (Fauset et al. 2015) and food webs (Zona and Henderson 1989), and their abundance varies with topography and edaphic conditions, and are dominating elements in wetlands (Myers 2013).

Nonetheless, developing allometric models specific for palms will increase the accuracy of the estimates of carbon stocks of tropical forests, since it is necessary to refine the models currently in use to include other life forms (e.g., lianas, epiphytes, tree ferns), which although they are not as abundant as trees, have relevant ecological roles and vary their abundance according to forest type, elevation, and edaphic factors.

Allometric analyses integrating palm biomass in studies of carbon stocks in tropical forests remain scarce (but see Nascimento and Laurance 2002; Lima et al. 2012). The accuracy of the allometric models obtained for the family Arecaceae would depend on the species composition of the palms included in the model. As of today, family-level models proposed for Arecaceae are based on a small number of species, showing a limited tribe representation and a relatively limited range of sizes and number of harvested individuals 
430 (i.e., Goodman et al. 2013; and this study). Many canopy palms frequently show heights

431 above or below those included in these models. Harvesting large individuals is difficult,

432 and many field sites do not allow it. In addition to sample size bias, allometric relationships

433 change geographically due to environmental conditions (Avalos et al. 2019), like

434 topography, edaphic factors, successional stage, climate, and nutrient availability

435 (Eiserhardt et al. 2011).

The accuracy of allometric models is hampered by an incomplete inventory of

437 functional characters for tropical plants, and especially for palms. Functional characters like 438 tissue density (Rich 1986, 1987), dmf, slenderness ratio, leaf toughness, and SLA, and even 439 stem height, as well as gas exchange characters, are rarely documented for palms as a 440 group, or are limited to individual species (i.e., Araus and Hogan 1994; da Silva et al. 2015; 441 Renninger and Phillips 2016). Much less is known about how these characters vary with 442 ontogenetic stage and palm size (but see Chazdon 1986a, 1986b). Tissue density, for 443 instance, varied with position along the stem as observed here, since sclerotized tissue is 444 denser closer to the base and periphery of the stem, and decreases in abundance close to the 445 top of the stem (Niklas 1992). The functional character databases are still data-deficient for 446 palms, and for tropical species in general, although Kissling et al. (2019) provide a very 447 comprehensive compilation. Still, these databases are based on a few individuals (e.g., 448 http://db.worldagroforestry.org), and often do not provide metadata. It is necessary to 449 incorporate more species, a larger sample size per species, a greater range of sizes, and 450 phylogenetic bias corrections. In addition, many tropical habitats where palms are very 451 abundant and dominant (Myers 2013) are not regularly inventoried for carbon stocks. 452 Despite these limitations, our classification of palms into forest strata showed a 453 clear segregation in structure between understory, subcanopy, and canopy species, as 
deduced from the principal component analysis. Understory species leaned towards characters reflecting biomass allocation such as slenderness value, dmf, and tissue density, whereas subcanopy and canopy species were associated with characters related to overall palm size, such as $\mathrm{DBH}$, total height and leaf area, although shoot:root ratios also influenced their allometric strategy. Palms in general have higher slenderness ratio than dicotyledonous trees (Niklas et al. 2006). Many understory palms display their leaf area with a high degree of efficiency by reducing leaf overlap and increasing light interception (Takenaka et al. 2001; Alvarez-Clare and Avalos 2007). Shade-adapted palms can complete their life cycle and reproduce in the understory, despite growing very slowly (Chazdon 1986b; Sylvester and Avalos 2013), but when light conditions improve, they can opportunistically increase their growth and reproductive performance (Chazdon 1986a; Gatti et al. 2011). For understory palms, resource allocation has a higher selective value, and once they surpass a height threshold and have more access to light, the selective advantage is to maintain high resource acquisition by increasing in size, which was the strategy of sub-canopy and canopy species. The ample morphological variation shown in the space defined by the first two principal components demonstrates these general trends and illustrates the diversity of allometric strategies within understory and canopy species. Functional characters such as dmf and tissue density showed a relatively high correlation coefficient (0.37), but their influence predicting carbon content was significant only in G. interrupta. Tissue density was not important in predicting carbon content for the rest of the species. A similar conclusion was reached by Goodman et al. (2013), although they did not measure tissue density directly and obtained their values from online databases. Dmf and tissue density were also correlated in Goodman et al. (2013)’s palm assemblage, and ultimately improved their mixed species model estimates of AGB. We 
478 found significant but small differences in tissue density depending on stem position, and

479 lower tissue density in canopy species relative to understory species. Chave et al. (2014)'s

480 model incorporated wood density, and once we applied this model to our subset of palm

481 species, the results were practically equivalent to the general palm model generated here.

482 The relative high fit of the Chave et al. (2014) model to our data could have been

483 influenced by having many palm species with a significant DBH vs. height relationship.

484 Consequently, the model of Chave et al. (2014) did not overestimate palm carbon content in 485 this case.

486 For most palms for which we have allometry data, there was a significant

487 relationship between DBH and stem height (Avalos et al. 2019). However, this relationship

488 is dependent on the palm species and phylogenetic relationships. It is erroneous to assume

489 that all palms have a fixed and decoupled relationship between DBH and stem height, a

490 view that is often prevalent in the literature (e.g., Tregear et al. 2011; Muscarella et al.

491 2020). Instead, some palm species could gradually increase DBH as they increase in height

492 through sustained primary growth (i.e., through the division, lignification, and expansion of

493 parenchyma cells, which can also differentiate into fibers, Tomlinson 2006, 2011), whereas

494 others must create sufficient DBH support early in life before increasing in height. Usually,

495 the relationship between DBH and stem height is logarithmic. In some species the

496 relationship is strong (e.g., S. exorrhiza, I. deltoidea, E. precatoria, P. decurrens), in others

497 it is intermediate (e.g., G. interrupta, $\mathrm{R}^{2}=0.42, \mathrm{P}=0.04, \mathrm{~N}=10$, Avalos et al. 2019), and

498 finally, some species do not show a significant relationship (e.g., M. flexuosa, Goodman et

499 al. 2013).

500 The diversity of palm growth forms (arborescent, acaulescent, climbing) makes it 501 difficult to standardize data collection to generate family-specific allometric models. For 
502

503

504

505

506

507

508

509

510

511

512

513

514

515

516

517

518

519

520

521

522

523

524

525

instance, we measured the total stem height from the ground to the base of the leaf crown, whereas in other studies (e.g., Goodman et al. 2013; Chave et al. 2014), total stem height was measured from the ground to the highest point of the plant, which may include the last leaf, with or without stilt roots, if present. We measured AGB from the base of the stem to the apex of the meristem, without including the cone of stilt roots; this cone is produced above the ground but was instead considered part of the below-ground biomass. Similarly, in A. martiana part of the stem grows underground, but we considered it as part of AGB.

Dioecious palms, like $C$. tepejilote, may differ in biomass allocation between sexes, which was the case for in the study of Oyama and Dirzo (1988), although they harvested 15 individuals, including male and female plants, and juveniles. In our case, we did not find differences in allometric patterns between male and female plants and juveniles. Oyama and Dirzo (1988)'s study was based on the follow up of 810 individuals in a more comprehensive demographic study. In other studies, stem height is not measured directly but inferred from species descriptions (de Castilho et al. 2006). Although there are efforts to standardize the measurement of functional characters (e.g., Perez-Harguindeguy et al. 2013), these are still focused on woody plants and do not consider the structural and morphological diversity of other plant groups.

\section{Estimation of root biomass and carbon content}

Estimation of root biomass and carbon content continue to be a major gap in palm allometric analyses. The data is still fragmentary and often restricted to a few individual species (e.g., Goodman et al. 2013; da Silva et al. 2015), hence much of the information is concentrated on aerial biomass. The functional ecology of roots is still poorly understood in general, especially with regards to the integration of above and below-ground characters. 
526 For example, leaf life span does not correlate with fine root longevity when resources are

527 limited (Weemstra et al. 2016). Under these conditions, leaves with long lifespans are

528 favored, but fine roots, responsible for increasing surface area and absorption capacity,

529 show a high turnover rate. Future research should be focused on analyzing the level of

530 integration between above and below-ground functional traits (Laliberté 2017). In our case,

531 similarly to other studies trying to estimate root biomass (e.g., da Silva et al. 2015), it was

532 difficult to obtain all roots, especially fine roots. Many palm species have superficial roots,

533 which may explain their predominance in flooded environments and very wet forests,

534 which are rich in palm species or are dominated by one or two species, since shallow roots

535 fare better in wet environments (Eiserhardt et al. 2011). There are very few studies

536 estimating root biomass for palms in the tropics (Frangi and Lugo 1985), so that

537 comparative information is difficult to come by, although da Silva et al. (2015) report the

538 same root:shoot ratio for E. precatoria found here.

540 Conclusions

541 After Goodman et al. (2013), this is the only recent study that has proposed a

542 family-level model to estimate not only AGC but also the total carbon content per

543 individual for the family Arecaceae. In addition to this model, we provided individual

544 models for 7 of the most common and abundant palm species in tropical rainforests and

545 estimated their below-ground biomass. Allometric models could have a high degree of

546 complexity by including many variables as well as a varied combination of them. Our

547 objective here was to simplify the selection of allometric models with practical importance

548 for forest inventories, as well as to explore the role of morphological variables on carbon

549 storage without proposing complex variable combinations. Most of the models that were 
statistically significant had a logarithmic form, which is consistent with the functional relationship between allometric characters, such as $\mathrm{DBH}$, stem height, and other traits related to palm size. It is necessary to include more species, a greater diversity of growth forms, a greater range of sizes, and larger sample size to improve the accuracy of allometric models in general, and for palms in particular. Palm species dominating wetlands continue to be deficient in this regard; despite dominating carbon-rich environments, there are few studies that include them, possibly due to the logistical difficulties of doing research in flooded environments. Finally, a better standardization of data collection is required to make progress in the estimation of carbon content using allometric methods, which continue to be a viable and efficient alternative to estimate carbon stocks.

\section{Acknowledgements}

Orlando Vargas facilitated field work at La Selva. Juan Manuel Ley facilitated field work at Tirimbina. Nutrient analyses were facilitated by Floria Bertsch at the Centro de Investigaciones Agronómicas, University of Costa Rica, and by Steven Jansen at the Department of Systematic Botany and Ecology, University of Ulm. The Alpízar Chaves family of El Progreso facilitated work in their property.

Funding: This investigation was supported by a research grant from the International Palm Society to MC, and scholarships from the Organization for Tropical Studies (MC and CAV), the University of Costa Rica (MC), and Tirimbina Biological Reserve (CAV). The School for Field Studies provided logistic support.

Ethics approval: The Ministry of the Environment of Costa Rica granted the respective research permits to carry out this research. 
573 Availability of data and materials: The datasets used and/or analyzed during the current

574 study are available from the corresponding author on reasonable request.

575

576

577

578 


\section{References}

Achard F, Eva HD, Mayaux P, Stibig HJ, Belward A (2004) Improved estimates of net carbon emissions from land cover change in the tropics for the 1990's. Global Biobeochem Cy 18:1-11 doi:10.1029/2003GB002142

Araus JL, Hogan KP (1994) Leaf structure and patterns of photoinhibition in two neotropical palms in clearings and forest understory during the dry season. Am J Bot 81:726-738 doi: 10.1002/j.1537-2197.1994.tb15507.x

Ares A, Boniche J, Quesada JP, Yost R, Molina E, Smyth TJ (2002) Estimación de biomasa por métodos alométricos, nutrimentos y carbón en plantaciones de palmito en Costa Rica. Agron Costarric 26:19-30

Avalos G, Schneider R (2011) Quantification of ramet production in the neotropical palm Euterpe precatoria (Arecaceae) in Costa Rica. Ecotropica 17:95-102

Avalos G, Gei M, Ríos LD, Otárola MF, Cambronero M, Alvarez-Vergnan C, Sylvester O, Rojas G (2019) Scaling of stem diameter and height allometry in 14 neotropical palm species of different forest strata. Oecologia 190(4):757-767 doi: $10.1007 / \mathrm{s} 00442-019-04452-7$

Baker WJ, Dransfield J (2016) Beyond Genera Palmarum: progress and prospects in palm systematics. Bot J Linn Soc 182:207-233 doi: 10.1111/boj.12401

Brando PM, Paolucci L, Ummenhofer CC, Ordway EM, Hartmann H, Cattau ME, ... Balch J (2019) Droughts, wildfires, and forest carbon cycling: A pantropical synthesis. Annu Rev Earth P1 Sc 47:555-581 doi: 10.1146/annurev-earth-082517010235

Brown S (1997) Estimating biomass and biomass change of tropical forests: a primer. FAO Forestry Paper -134, Illinois 
603

604

605

606

607

608

609

610

611

612

613

614

615

616

617

618

619

620

621

622

623

624

625

Cambronero M, Avalos G, Alvarez-Vergnani C (2018) Variation in the carbon fraction of seven neotropical palm species of different forest strata. Palms 62(1):25-34.

Canadell JG, Raupach MR (2008) Managing forests for climate change mitigation. Science 320:1456-1457 doi: 10.1126/science.1155458

Castillo-Mont JJ, Gallardo NR, Johnson DV (1994) The pacaya palm (Chamaedorea tepejilote, Arecaceae) and its food use in Guatemala. Econ Bot 48:68-75 doi: 10.1007/BF02901383

Chave J, Andalo C, Brown S, Cairns MA, Chambers J Q, ... Yamakura T (2005) Tree allometry and improved estimation of carbon stocks and balance in tropical forests. Oecologia 145:87-99 doi: 10.1007/s00442-005-0100-x

Chave J, Réjou-Méchain M, Búrquez A, Chidumayo E, Colgan M, Delitti W, ... Vieilledent G (2014) Improved allometric models to estimate the aboveground biomass of tropical trees. Glob Change Biol 20:3177-3190 doi: 10.1111/gcb.12629

Chazdon RL (1986a) Light variation and carbon gain in rain forest understorey palms. $\mathbf{J}$ Ecol 74:995-1012 doi: 10.2307/2260229

Chazdon RL (1986b) Physiological and morphological basis of shade tolerance in rain forest understory palms. Principes 30:92-99

Clark DB, Clark DA (2000) Landscape-scale variation in forest structure and biomass in a tropical rain forest. Forest Ecol Manag 137:185-198 doi: 10.1016/S03781127(99)00327-8

Clark DA, Brown S, Kicklighter DW, Chambers JQ, Thomlinson JR, Ni J (2001) Measuring net primary production in forests: Concepts and field methods. Ecol Appl 11:356-370 doi: 10.1890/1051-0761(2001)011 
626 Clark DA (2007) Detecting tropical forests' response to global climatic and atmospheric

627 change: current challenges and a way forward. Biotropica, 39:4-19 doi:

628 10.1111/j.1744-7429.2006.00227.x

629 Curtis PS (2008) Estimating aboveground carbon in live and standing dead trees. In:

630 Hoover CM (ed) Field measurements for forest carbon monitoring, a landscape-

631 scale approach. Springer, New York, pp 39-44

632 Da Silva F, Suwa R, Kajimoto T, Ishizuka M, Higuchi N, Kunert N (2015) Allometric

633 equations for estimating biomass of Euterpe precatoria, the most abundant palm

634 species in the Amazon. Forests 6:450-463 doi: 0.3390/f6020450

635 Dargie GC, Lewis SL, Lawson IT, Mitchard ET, Page SE, Bocko YE, Ifo SA (2017)

636 Age, extent and carbon storage of the central Congo Basin peatland complex.

$637 \quad$ Nature 542:86-90 doi: 10.1038/nature21048

638 de Castilho CV, Magnusson WE, de Araújo RNO, Luizao RC, Luizao FJ, Lima AP,

639 Higuchi N (2006) Variation in aboveground tree live biomass in a central

640 Amazonian Forest: Effects of soil and topography. Forest Ecol Manag 234:85-96

641 doi: $10.1016 /$ j.foreco.2006.06.024

642 DeWalt SJ, Chave J (2004) Structure and biomass of four lowland Neotropical forests.

$643 \quad$ Biotropica 36:7-19 doi: 10.1111/j.1744-7429.2004.tb00291.x

644 Dewar RC (1991) Analytical model of carbon storage in the trees, soils and wood

645 products of managed forests. Tree Physiology 8:239-258 doi: $10.1111 / \mathrm{j} .1744-$

$646 \quad$ 7429.2004.tb00291.x

647 Dewar RC, Cannell MGR (1992) Carbon sequestration in the trees, products and soils of

648 forest plantations using UK samples. Tree Physiol 11:49-71 doi:

649

10.1093/treephys/11.1.49 
Díaz S, Settel J, Brondízio ES, Ngo HT, Guèze M, Agard J, ... Zayas C (2019) Summary for policymakers of the global assessment report on biodiversity and ecosystem services of the Intergovernmental Science-Policy Platform on Biodiversity and Ecosystem Services. Intergovernmental Science-Policy Platform on Biodiversity and Ecosystem Services

Dransfield JN, Uhl W, Amussen CB, Baker WHJ, Harley MM, Lewis CE (2008) Genera Palmarum: the evolution and classification of palms. London, Kew Publishing Royal Botanic Gardens

Eiserhardt WL, Svenning JC, Kissling WD, Balslev H (2011) Geographical ecology of the palms (Arecaceae): determinants of diversity and distributions across spatial scales. Ann Bot 108:1391-1416 doi: 10.1093/aob/mcr146

Ekadinata AE, Khasanah N, Rahayu S, Budidarsono S, van Noordwijk M (2010) Carbon footprint of Indonesian palm oil production: sample design and methodology. World Agroforestry Centre, International Centre for Research in Agroforestry, Indonesia

Fauset S, Johnson MO, Gloor M, Baker TR, Monteagudo A, Brienen RJ, ... Phillips OL (2015) Hyperdominance in Amazonian forest carbon cycling. Nat Commun 61-9. doi:10.1038/ncomms7857

Feldpausch TR, Banin L, Phillips OL, Baker TR, Lewis SL, Quesada CA, ... Lloyd J (2011) Height-diameter allometry of tropical forest trees. Biogeosciences 8:10811106 doi: 10.5194/bg-8-1081-2011

Frangi JL, Lugo AE (1985) Ecosystem dynamics of a subtropical floodplain forest. Ecol Monogr 55:351-369 doi: 10.2307/1942582 
673 Friedlingstein P, O'Sullivan M, Jones MW, Andrew RM, Hauck J, Olsen A, ... Zaehle S

674 (2020) Global carbon budget 2020. Earth Sys Sci Data 12:3269-3340 doi:

$675 \quad 10.5194 /$ essd-12-3269-2020

676 Gatti MG, Campanello PI, Goldstein G (2011) Growth and leaf production in the 677 tropical palm Euterpe edulis: Light conditions versus developmental constraints.

678 Flora-Morphology, Distribution, Functional Ecology of Plants 206:742-748 doi:

$679 \quad$ 10.1016/j.flora.2011.04.004

680 Goers L, Ashton MS, Tyrrell ML (2012) Introduction. In: Ashton MS, Tyrrell ML,

681 Spalding D, Gentry B (eds) Managing forest carbon in a changing climate.

$682 \quad$ Springer, Netherlands pp 1-4

683 Goodman R, Phillips OL, Torres D, Freitas L, Tapia-Cortese S, Monteagudo A, Baker T

684 (2013) Amazon palm biomass and allometry. Forest Ecol Manag 310:994-1004

685 doi: $10.1016 /$ j.foreco.2013.09.045

686 Grayum MH (2003) Arecaceae. In: Hammel BE, Grayum MH, Herrera C, Zamora N

687 (eds), Manual de Plantas de Costa Rica, Vol. III. Missouri Botanical Garden, St.

$688 \quad$ Louis pp 201-293

689 Hairiah K, Sitompul SM, van Noordwijk M, Palm C (2001) Methods for sampling

690 carbon stocks above and below ground. International Centre for Research in

691 Agroforestry, Southeast Asian Regional Research Programme, Indonesia

692 Henderson A (1995) The palms of the Amazon. Oxford University Press, New York

693 Henderson A, Galeano G, Bernal R (1995) Field guide to the Palms of the Americas.

694 Princeton University Press, New York

695 Henderson A (2002) Evolution and ecology of palms. New York Botanical Garden, New

$696 \quad$ York 
Houghton RA (2007) Balancing the global carbon budget. Annu Rev Earth Pl Sc 35:313-347 doi: 10.1146/annurev.earth.35.031306.140057

Howard FW, Moore D, Giblin-Davis RM, Abad RG (2001) Insects on palms. CABI Publishing, Wallingford

Jones DL (1995) Palms throughout the world. Smithsonian Institution Press, Washington DC

Jucker T, Caspersen J, Chave J, Antin C, Barbier N, Bongers F, ... Coomes DA (2017) Allometric equations for integrating remote sensing imagery into forest monitoring programmes. Glob Change Biol 23:177-190 doi: 10.1111/gcb.13388

Khasanah N, van Noordwijk M, Ekadinata A, Dewi S, Rahayu S, Ningsih H, ...

Octaviani R (2012) The carbon footprint of Indonesian palm oil production. (Technical Brief No 25: Palm oil series). World Agroforestry Centre - ICRAF, SEA Regional Office, Indonesia

Kissling WD, Balslev H, Baker WJ, Dransfield J, Göldel B, Lim JY, ... Svenning JC (2019) PalmTraits 1.0, a species-level functional trait database of palms worldwide. Sci Data 6:1-13 doi: 10.1038/s41597-019-0189-0

Lähteenoja O, Ruokolainen K, Schulman L, Oinonen M (2009) Amazonian peatlands: an ignored C sink and potential source. Glob Change Biol 15:2311-2320 doi: 10.1111/j.1365-2486.2009.01920.x

Lal R (2008) Carbon sequestration. Philos T Roy Soc B 363:815-830 doi: 10.1098/rstb.2007.2185

Laliberté E (2017) Below-ground frontiers in trait-based plant ecology. New Phytol 213:1597-1603 doi: 10.1111/nph.14247 
Leblanc H, Russo R, Cueva JJ, Subía E (2006) Fijación de carbono en palma aceitera en la región tropical húmeda de Costa Rica. Tierra Tropical 2:197-202

LECO Corporation (2006) TruSpec CN Carbon/Nitrogen determinator, instruction manual. Software version 1.6x. LECO Corporation, Miami

Lima AJN, Suwa R, de Mello Ribeiro GHP, Kajimoto T, dos Santos J, da Silva RP, ... Higuchi N (2012) Allometric models for estimating above-and below-ground biomass in Amazonian forests at São Gabriel da Cachoeira in the upper Rio Negro, Brazil. Forest Ecol Manag 277:163-172 doi: 10.1016/j.foreco.2012.04.028

Lorenz K, Lal R (2010) Carbon sequestration in forest ecosystems. Springer Verlag, Berlin

McDade LA (1994) La Selva: Ecology and natural history of a neotropical rainforest. University of Chicago Press, Chicago

Mejia K, Kahn F (1990) Palm Communities in Wetland Forest Ecosystems of Peruvian Amazonia. Forest Ecol Manag 33-34:169-179 doi: 10.1016/0378-1127(90)90191-

\section{$\mathrm{D}$}

Montero M, Montagnini F (2005) Modelos alométricos para la estimación de biomasa de diez especies nativas en plantaciones en la región Atlántica de Costa Rica. Recursos Naturales y Ambiente 45:112-119

Myers RL (2013) Humedales dominados por palmas (Arecaceae) en el Neotrópico: Una introducción. Rev Biol Trop 61:5-24

Muscarella R, Emilio T, Phillips OL, Lewis SL, Slik F, Baker WJ, ... Poedjirahajoe E (2020) The global abundance of tree palms. Glob Ecol Biogeogr 29:1495-1514 doi: $10.1111 /$ geb.13123 
Nascimento HE, Laurance WF (2002) Total aboveground biomass in central Amazonian rainforests: a landscape-scale study. Forest Ecol Manag 168:311-321 doi: 10.1016/S0378-1127(01)00749-6

Niklas KJ (1992) Plant biomechanics: an engineering approach to plant form and function. The University of Chicago Press, Chicago

Niklas KJ, Cobb ED, Marler T (2006) A comparison between the record height-to-stem diameter allometries of pachycaulis and leptocaulis species. Ann Bot 97:79-83 doi: 10.1093/aob/mcj002

Onstein RE, Baker WJ, Couvreur TL, Faurby S, Svenning JC, Kissling WD (2017) Frugivory-related traits promote speciation of tropical palms. Nat Ecol Evol 1:1903-1911 doi: 10.1038/s41559-017-0348-7

Oyama K, Dirzo R (1988) Biomass allocation in the dioecious tropical palm Chamaedorea tepejilote and its life history consequences. Plant Spec Biol 3:27-33 doi: 10.1111/j.1442-1984.1988.tb00168.x

Perez-Harguindeguy N, Diaz S, Garnier E, Lavorel S, Poorter H, Jaureguiberry P, ... Cornelissen JHC (2013) New handbook for standardised measurement of plant functional traits worldwide. Aust. Bot. 61:167-234. doi: 10.1071/BT12225

Pulhin FB, Lasco RD, Urquiola JP (2014) Carbon sequestration potential of oil palm in Bohol, Philippines. Ecosystems \& Development Journal 4:14-19

Renninger HJ, Phillips NG (2016) Palm physiology and distribution in response to global environmental change. In: Goldstein G, Santiago LS (eds), Tropical Tree Physiology. Springer, Switzerland, pp 67-101

Rich P (1986) Mechanical architecture of arborescent rain forest palms. Principes 30:117-131 
Rich PM (1987) Mechanical structure of the stem of arborescent palms. Bot Gaz 148:4250.

Rodríguez-Veiga P, Quegan S, Carreiras J, Persson HJ, Fransson JE, Hoscilo A, ... Balzter H (2019) Forest biomass retrieval approaches from earth observation in different biomes. Int J Appl Earth Obs 77:53-68. doi: 10.1016/j.jag.2018.12.008 Sampaio MB, Schmidt IB, Figueiredo IB (2008) Harvesting effects and population ecology of the buriti palm (Mauritia flexuosa L. f., Arecaceae) in the Jalapão Region, Central Brazil. Econ Bot 62:171-181 doi: 10.1007/s12231-008-9017-8

Serrano-Sandí J, Bonilla-Murillo F, Sasa M (2013) Distribución, superficie y área protegida de humedales dominados por pantanos de palmas (Arecaceae) en Costa Rica y Nicaragua. Rev Biol Trop 61:25-33

Sprugel DG (1983) Correcting for bias Log-transformed allometric equations. Ecology 64:209-210 doi: 10.2307/1937343

Steffen W, Rockström J, Richardson K, Lenton TM, Folke C, Liverman D, ... Schellnhuber HJ (2018) Trajectories of the Earth System in the Anthropocene. Proc Natl Acad Sci USA 15:8252-8259 doi: 10.1073/pnas.1810141115

Syahrinudin (2005) The potential of oil palm and forest plantations for carbon sequestration on degraded land in Indonesia. Ecology and Development Series 28, Germany Sylvester O, Avalos G, Chávez-Fernández N (2012) Notes on the ethnobotany of Costa Rica’s palms. Palms 56:190-201

Sylvester O, Avalos G (2013) Influence of light conditions on the allometry and growth of the understory palm Geonoma undata subsp. edulis (Arecaceae) of neotropical cloud forests. Am J Bot 100:1-7. doi: 10.3732/ajb.1300247 
ter Steege H, Pitman NCA, Sabatier D, Baraloto C, Salomão RP, Guevara JE, ... Silman MR (2013) Hyperdominance in the Amazonian tree flora. Science 342:325-342 doi: 10.1126/science. 1243092

Thenkabail PS, Stucky N, Griscom BW, Ashton MS, Diels J, Van Der Meer B, Enclona E (2004) Biomass estimations and carbon stock calculations in the oil palm plantations of African derived savannas using IKONOS data. Int J Remote Sens 25:1-27 doi: 10.1080/01431160412331291279

Tomlinson PB (2006) The uniqueness of palms. Bot J Linn Soc 151:5-14 doi: 10.1111/j.1095-8339.2006.00520.x Tomlinson PB (2011) The anatomy of palms. Oxford University Press, New York Tregear JW, Rival A, Pintaud JC (2011) A family portrait: unravelling the complexities of palms. Ann Bot 108:1387-1389 doi: 10.1093/aob/mcr269

Weemstra M, Mommer L, Visser EJ, van Ruijven J, Kuyper TW, Mohren GM, Sterck FJ (2016) Towards a multidimensional root trait framework: a tree root review. New Phytol 211:1159-1169 doi: 10.1111/nph.14003

Yaap B, Watson H, Laurance WF (2015) Mammal use of Raphia taedigera palm stands in Costa Rica’s Osa Peninsula. Mammalia 79:357-362 doi: 10.1515/mammalia2014-0033

Zhang X, Zhao Y, Ashton MS, Lee X (2012) Measuring carbon in forests. In: Ashton MS, Tyrrell ML, Spalding D, Gentry B (eds), Managing forest carbon in a changing climate. Springer, Netherlands, pp 139-164

Zona S, Henderson A (1989) A review of animal-mediated seed dispersal of palms. Selbyana 11:6-21 


\begin{tabular}{|c|c|c|c|c|c|c|c|c|c|c|c|c|c|c|c|c|c|c|c|}
\hline $\begin{array}{c}\text { Species } \\
\text { (Abbreviation) } \\
\end{array}$ & Stratum & Tribe' & $\mathrm{N}$ & DBH (cm) & $\mathrm{H}(\mathrm{m})$ & $\begin{array}{c}\text { Tissue density } \\
\left(\mathrm{g} / \mathrm{cm}^{2}\right)\end{array}$ & $\begin{array}{c}\text { Total dry biomass } \\
(\mathrm{kg})\end{array}$ & AGB $(\mathrm{kg})$ & Number of leaves & Leaf area $\left(\mathrm{m}^{2}\right)$ & $\begin{array}{c}\text { Dry weight leaves } \\
(\mathrm{kg})\end{array}$ & $\begin{array}{c}\text { Dry weight stem } \\
\text { (kg s) }\end{array}$ & $\begin{array}{c}\text { Dry weight roots } \\
(\mathrm{kg})\end{array}$ & $\begin{array}{c}\text { Carbon in leaves } \\
(\mathrm{kg})\end{array}$ & $\begin{array}{c}\text { Carbon in stems } \\
(\mathrm{kg})\end{array}$ & $\begin{array}{c}\text { Carbon in roots } \\
(\mathrm{kg})\end{array}$ & $\begin{array}{c}\text { Total carbon per } \\
\text { palm (kg) }\end{array}$ & $\begin{array}{c}\begin{array}{c}\text { Root:shoot } \\
\text { (carbon) }\end{array} \\
\text { (c) }\end{array}$ & $\begin{array}{l}\text { Root:shoot } \\
\text { (biomass) }\end{array}$ \\
\hline $\begin{array}{l}\bar{A} \text { Astergogyne } \\
\text { martiana }(A M)\end{array}$ & Understory & Geonomateae & 15 & $2.5(1.53-3.88)$ & $0.78(0.28-1.66)$ & $0.35(0.26-0.51)$ & $0.3(0.02-0.63)$ & $0.05(0.005-0.12)$ & 9 to 26 & $1.17(0.13-3.04)$ & $0.10(0.0003-0.29)$ & $0.16(0.005-0.4)$ & $0.03(0.002-0.08)$ & $0.04(0.005-0.13)$ & $0.07(0.002-0.18)$ & $0.01(0.001-0.03)$ & $0.3(0.02-0.063)$ & $0.16(0.032-0.36)$ & $0.6(0.11-2.54)$ \\
\hline $\begin{array}{l}\text { Chamaedorea } \\
\text { tepepilote (CT) }\end{array}$ & Understory & $\begin{array}{l}\text { Cha } \\
\text { ae }\end{array}$ & 22 & $3.04(1.27-5.09)$ & $2.82(0.55-6.72)$ & $0.31(0.14-0.6)$ & $0.9(0.05-2.93)$ & $0.32(0.011-1.2)$ & 3106 & $2.34(0.22-4.65)$ & $0.14(0.02-0.34)$ & $0.48(0.01-2)$ & $0.28(0.006-1.14)$ & $0.06(0.02-0.15)$ & $0.2(0.006-0.89)$ & $0.12(0.003-0.51)$ & $0.9(0.04-2.93)$ & $0.51(0.10-2.54)$ & $0.2(0.03-0.76)$ \\
\hline 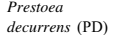 & Understory & Euterpeae & 10 & $6.74(5.0-8.6)$ & $6.31(1.1-11.5)$ & $0.34(0.1-0.6)$ & $9.16(0.85-21.1)$ & $2.88(0.34-7.76)$ & 5 to 12 & $8.8(1.67-18.01)$ & $3.8(0.76-5.8)$ & $11.34(0.37-28.41)$ & $5.57(0.63-17.23)$ & $1.64(0.31-2.46)$ & $4.92(0.14-12.34)$ & $2.6(0.28-7.89)$ & $9.15(0.85-21.1)$ & $0.40(0.17-0.84)$ & $0.38(0.16-0.78)$ \\
\hline 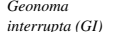 & Understory & Geonomateae & 10 & $6.74(5-8.8)$ & $4.48(0.69-11.62)$ & $0.34(0.16-0.48)$ & $12.7(0.4-54.51)$ & $3.68(0.2-14.53)$ & 6 to 20 & $7.9(1.58-25.04)$ & $1.18(0.14-5.16)$ & $7.4(0.23-32.68)$ & $4.12(0.02-19.64)$ & $0.5(0.06-2.21)$ & $3.28(0.08-14.66)$ & $1.66(0.01-6.66)$ & $12.7(0.4-54.51)$ & $0.36(0.07-0.56)$ & $0.36(0.07-0.56)$ \\
\hline $\begin{array}{l}\text { ipe } \\
\text { atorit }\end{array}$ & bcanopy & Euterpeae & 10 & $7.03(3.5-12.8)$ & $7.01(2.2-12.6)$ & $0.2(0.15-0.26)$ & $5.55(0.36-27.14)$ & $4.38(0.33-14.75)$ & 5 to 9 & $10.5(2.6-28.66)$ & $2.26(0.57-10.1)$ & $8.14(0.08-42.97)$ & $2.06(0.08-7.89)$ & $1.06(0.26-4.78)$ & $3.54(0.03-18.75)$ & $0.94(0.03-3.59)$ & $5.55(0.36-27.14)$ & $0.26(0.02-1.28)$ & $0.25(0.02-1.24)$ \\
\hline tidea (ID) & Canopy & Iriarteaea & 10 & $12.03(4.4-23.6)$ & $5.93(1.0-11.5)$ & $0.14(0.08-0.02)$ & $8.26(0.22-28.46)$ & $11.78(0.24-39.17)$ & 5 to 9 & $25.86(2.63-79.66)$ & $6.16(0.34-20.92)$ & $11.01(0.07-41.94)$ & $2.19(0.07-8.82)$ & $2.6(0.14-9.0)$ & $4.68(0.02-17.84)$ & $0.97(0.03-3.84)$ & $8.25(0.22-28.46)$ & $0.15(0.02-0.36)$ & $0.14(0.01-0.31)$ \\
\hline $\begin{array}{l}\text { ocratea } \\
\text { overhiza (SE) }\end{array}$ & Canopy & Iriarteae & 10 & $12.86(2.4-420)$ & $8.0(1.4-14.8)$ & $17(0.09-0.38)$ & $16.22(0.09-58.06)$ & $14.24(0.11-34.64)$ & 3 to 11 & $21.4(1.28-53.31)$ & $5.62(0.08-15.96)$ & $17.64(0.02-63.19)$ & $12.64(0.11-49.16)$ & $2.54(0.04-7.25)$ & $7.83(0.008-28.62)$ & $5.85(0.05-22.92)$ & $16.22(0.09-58.06)$ & $0.83(0.31-1.9)$ & $0.78(0.31-1.7)$ \\
\hline
\end{tabular}

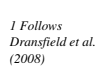


Table 2. Models to estimate carbon content (C; $\mathrm{kg})$, in 7 species of neotropical palms. DBH: Diameter at breast height $(\mathrm{cm}), \mathrm{H}_{\mathrm{tot}}$ : Total height $(\mathrm{m}), \mathrm{H}_{\mathrm{bc}}$ : Height at the base of the crown $(\mathrm{m}), \rho$ : density of the sclerotized tissue $\left(\mathrm{g} / \mathrm{cm}^{3}\right)$. CF: Correction factor recommended by Sprugel (1983). MSE: Mean square of error. AIC: Akaike's information criteria. Ln:

Natural logarithm. The most parsimonious model is highlighted in bold-faced.

\begin{tabular}{|c|c|c|c|c|c|c|c|c|}
\hline Species & & Model & $\mathbf{C F}$ & $\mathbf{R}^{2}$ & $\mathbf{F}$ & $\mathbf{P}$ & MSE & AIC \\
\hline \multirow[t]{10}{*}{ Socratea exorrhiza } & $\operatorname{Ln}(\mathrm{C})$ & $\begin{array}{l}-5.25+2.91 \\
\operatorname{Ln}(\mathrm{DBH})\end{array}$ & 1.01 & 0.92 & 101.8 & $<0.0001$ & 2.56 & -9.61 \\
\hline & $\operatorname{Ln}(\mathrm{C})$ & $\begin{array}{l}-2.71+2.43 \\
\operatorname{Ln}\left(\mathrm{H}_{\mathrm{tot}}\right)\end{array}$ & 1.16 & 0.95 & 182.77 & $<0.0001$ & 1.47 & -15.14 \\
\hline & $\operatorname{Ln}(\mathrm{C})$ & $\begin{array}{l}-1.64+2.16 \\
\operatorname{Ln}\left(H_{b c}\right)\end{array}$ & 1.16 & 0.94 & 126.52 & $<0.0001$ & 2.09 & -11.64 \\
\hline & $\operatorname{Ln}(\mathrm{C})$ & $4.1+1.26 \operatorname{Ln}(\rho)$ & n.s. & 0.08 & 0.67 & 0.44 & 4.05 & 15.8 \\
\hline & $\operatorname{Ln}(\mathrm{C})$ & $\begin{array}{l}1.37-0.2 \\
\operatorname{Ln}(\mathrm{dmf})\end{array}$ & n.s. & 0.0009 & 0.03 & 0.94 & 4.4 & 16.56 \\
\hline & $\operatorname{Ln}(C)$ & $-2.6+0.34 \mathrm{DBH}$ & 1.06 & 0.97 & 280.74 & $<0.0001$ & 0.97 & -19.28 \\
\hline & $\operatorname{Ln}(C)$ & $-1.29+0.38 \mathrm{H}_{\mathrm{tot}}$ & 1.3 & 0.88 & 57.37 & $<0.0001$ & 0.54 & -4.4 \\
\hline & $\operatorname{Ln}(\mathrm{C})$ & $-1.1+0.44 \mathrm{H}_{b c}$ & 1.3 & 0.88 & 57.76 & $<0.0001$ & 0.53 & -4.49 \\
\hline & $\operatorname{Ln}(\mathrm{C})$ & $0.3+8.49 \rho$ & n.s. & 0.14 & 1.4 & 0.27 & 3.74 & 14.96 \\
\hline & $\operatorname{Ln}(\mathrm{C})$ & $2.01-1.58 \mathrm{dmf}$ & n.s. & 0.001 & 0.0009 & 0.92 & 4.4 & 16.56 \\
\hline Combined model & $\operatorname{Ln}(C)$ & $\begin{array}{l}-4.1+0.89 \\
\operatorname{Ln}(\mathrm{DBH})+2.97 \\
\operatorname{Ln}\left(H_{\text {tot }}\right)-1.1 \\
\operatorname{Ln}\left(\mathbf{H}_{\text {bc }}\right)\end{array}$ & 1.06 & 0.97 & 65.35 & $<0.0001$ & 0.17 & -14.59 \\
\hline \multirow[t]{4}{*}{ Iriartea deltoidea } & $\operatorname{Ln}(C)$ & $\begin{array}{l}-4.43+2.48 \\
\mathrm{Ln}(\mathrm{DBH})\end{array}$ & 1.07 & 0.94 & 150.18 & $<0.0001$ & 0.13 & -18.16 \\
\hline & $\operatorname{Ln}(C)$ & $\begin{array}{l}-1.64+1.92 \\
\operatorname{Ln}\left(H_{t o t}\right)\end{array}$ & 1.11 & 0.91 & 87.26 & $<0.0001$ & 0.22 & -13.18 \\
\hline & $\operatorname{Ln}(C)$ & $\begin{array}{l}-0.26+1.54 \\
\operatorname{Ln}\left(\mathrm{H}_{b c}\right)\end{array}$ & 1.25 & 0.83 & 40.12 & 0.0002 & 0.44 & -6.26 \\
\hline & $\operatorname{Ln}(\mathrm{C})$ & $\begin{array}{l}-1.96+22.29 \\
\operatorname{Ln}(\rho)\end{array}$ & n.s. & 0.19 & 1.8 & 0.2 & 2.18 & 9.56 \\
\hline
\end{tabular}




\begin{tabular}{|c|c|c|c|c|c|c|c|c|}
\hline & $\operatorname{Ln}(\mathrm{C})$ & $\begin{array}{l}-3.96-2.62 \\
\operatorname{Ln}(d m f)\end{array}$ & n.s. & 0.21 & 2.22 & 0.17 & 2.1 & 9.22 \\
\hline & $\operatorname{Ln}(\mathrm{C})$ & $-1.14+0.2 \mathrm{DBH}$ & 1.12 & 0.92 & 86.86 & $<0.0001$ & 0.22 & -13.06 \\
\hline & $\operatorname{Ln}(\mathrm{C})$ & $-1.29+0.38 \mathrm{H}_{\mathrm{tot}}$ & 1.19 & 0.94 & 129.88 & $<0.0001$ & 0.16 & -16.79 \\
\hline & $\operatorname{Ln}(C)$ & $-0.68+0.53 \mathrm{H}_{\mathrm{bc})}$ & 1.3 & 0.8 & 32.85 & 0.0004 & 0.52 & -4.6 \\
\hline & $\operatorname{Ln}(C)$ & $-1.92+22.18 \rho$ & n.s. & 0.28 & 3.2 & 0.11 & 1.92 & 8.29 \\
\hline & $\operatorname{Ln}(\mathrm{C})$ & $3.78-17.86 \mathrm{dmf}$ & n.s. & 0.22 & 2.28 & 0.16 & 2.09 & 9.16 \\
\hline Combined model & $\operatorname{Ln}(C)$ & $\begin{array}{l}-3.52+1.58 \\
\operatorname{Ln}(\mathrm{DBH})+0.78 \\
\operatorname{Ln}\left(\mathrm{H}_{\text {tot }}\right)\end{array}$ & 1.04 & 0.97 & 116.9 & $<0.0001$ & 0.08 & -21.7 \\
\hline Euterpe precatoria & $\operatorname{Ln}(\mathrm{C})$ & $\begin{array}{l}-1.49+0.37 \\
\operatorname{Ln}(\mathrm{DBH})\end{array}$ & 1.04 & 0.94 & 134.3 & $<0.0001$ & 0.1 & -21.5 \\
\hline & $\operatorname{Ln}(\mathrm{C})$ & $\begin{array}{l}-1.39+0.37 \\
\operatorname{Ln}\left(\mathrm{H}_{\text {tot }}\right)\end{array}$ & 1.08 & 0.90 & 77.94 & $<0.0001$ & 0.16 & -16.46 \\
\hline & $\operatorname{Ln}(\mathrm{C})$ & $\begin{array}{l}-0.77+0.38 \\
\operatorname{Ln}\left(\mathrm{H}_{\mathrm{bc}}\right)\end{array}$ & 1.01 & 0.79 & 30.79 & 0.0005 & 0.36 & -8.5 \\
\hline & $\operatorname{Ln}(\mathrm{C})$ & $\begin{array}{l}-1.57+13.69 \\
\ln (\rho)\end{array}$ & n.s. & 0.16 & 1.48 & 0.25 & 1.46 & 5.58 \\
\hline & $\operatorname{Ln}(\mathrm{C})$ & $\begin{array}{l}2.18+0.54 \\
\operatorname{Ln}(\mathrm{dmf})\end{array}$ & n.s. & 0.21 & 2.22 & 0.17 & 2.1 & 9.22 \\
\hline & $\operatorname{Ln}(\mathrm{C})$ & $-1.5+0.38 \mathrm{DBH}$ & 1.06 & 0.93 & 114.86 & $<0.0001$ & 0.11 & -20.04 \\
\hline & $\operatorname{Ln}(C)$ & $-1.4+0.36 H_{\text {tot }}$ & 1.04 & 0.95 & 161.26 & $<0.0001$ & 0.08 & -23.24 \\
\hline & $\operatorname{Ln}(\mathrm{C})$ & $-0.77+0.38 \mathrm{H}_{b c}$ & 1.06 & 0.93 & 109.96 & $<0.0001$ & 0.94 & -19.62 \\
\hline & $\operatorname{Ln}(\mathrm{C})$ & $-1.6+13.91 \rho$ & n.s. & 0.15 & 1.42 & 0.26 & 1.47 & 5.65 \\
\hline & $\operatorname{Ln}(\mathrm{C})$ & $0.52+4.08 \mathrm{dmf}$ & n.s. & 0.22 & 2.28 & 0.16 & 2.09 & 9.16 \\
\hline $\begin{array}{l}\text { Chamaedorea } \\
\text { tepejilote }\end{array}$ & $\operatorname{Ln}(\mathrm{C})$ & $\begin{array}{l}-5.6+4 \\
\operatorname{Ln}(\mathrm{DBH})\end{array}$ & 1.02 & 0.66 & 38.59 & $<0.0001$ & 0.41 & -17.39 \\
\hline & $\operatorname{Ln}(C)$ & $\begin{array}{l}-2.4+1.29 \\
\operatorname{Ln}\left(\mathrm{H}_{\text {tot }}\right)\end{array}$ & 1.01 & 0.55 & 24.71 & $<0.0001$ & 0.54 & -11.45 \\
\hline & $\operatorname{Ln}(\mathrm{C})$ & $\begin{array}{l}-1.33+0.02 \\
\operatorname{Ln}(\rho)\end{array}$ & n.s. & 0.001 & 0.02 & 0.89 & 1.21 & 6.22 \\
\hline
\end{tabular}




\begin{tabular}{|c|c|c|c|c|c|c|c|c|}
\hline & $\operatorname{Ln}(\mathrm{C})$ & $\begin{array}{l}-0.68+0.49 \\
\operatorname{Ln}(\mathrm{dmf})\end{array}$ & n.s. & 0.01 & 0.36 & 0.55 & 1.2 & 5.84 \\
\hline & $\operatorname{Ln}(\mathrm{C})$ & $\begin{array}{l}-5.94+1.56 \\
\mathrm{DBH}\end{array}$ & 1.02 & 0.66 & 39.16 & $<0.0001$ & 0.41 & -17.6 \\
\hline & $\operatorname{Ln}(\mathrm{C})$ & $-2.56+0.42 \mathrm{H}_{\mathrm{tot}}$ & 1.03 & 0.76 & 65.22 & 0.0001 & 0.28 & -25.64 \\
\hline & $\operatorname{Ln}(\mathrm{C})$ & $-1.46+0.34 \rho$ & n.s. & 0. & 0.001 & 0.98 & 1.21 & 6.25 \\
\hline & $\operatorname{Ln}(\mathrm{C})$ & $-1.72+1.36 \mathrm{dmf}$ & n.s. & 0.02 & 0.59 & 0.45 & 1.18 & 5.6 \\
\hline Combined model & $\operatorname{Ln}(C)$ & $\begin{array}{l}-3.94+1.75 \\
\operatorname{Ln}(\mathrm{DBH})+0.89 \\
\operatorname{Ln}\left(\mathrm{H}_{\text {tot }}\right)\end{array}$ & 1.02 & 0.81 & 43.79 & $<0.0001$ & 0.23 & -29.43 \\
\hline \multirow[t]{10}{*}{ Prestoea decurrens } & $\operatorname{Ln}(\mathrm{C})$ & $\begin{array}{l}-8.67+5.58 \\
\operatorname{Ln}(\mathrm{DBH})\end{array}$ & 1.11 & 0.54 & 9.64 & 0.01 & 0.79 & -0.57 \\
\hline & $\operatorname{Ln}(\mathrm{C})$ & $\begin{array}{l}-0.81+1.64 \\
\operatorname{Ln}\left(H_{\text {tot }}\right)\end{array}$ & 1.02 & 0.86 & 51.66 & $<0.0001$ & 0.23 & -12.76 \\
\hline & $\operatorname{Ln}(\mathbf{C})$ & $\begin{array}{l}-0.08+1.53 \\
\operatorname{Ln}\left(H_{b c}\right)\end{array}$ & 1.05 & 0.87 & 55.06 & 0.0001 & 0.22 & -13.31 \\
\hline & $\operatorname{Ln}(\mathrm{C})$ & $\begin{array}{l}3.79+1.44 \\
\operatorname{Ln}(\rho)\end{array}$ & 1.22 & 0.76 & 25.96 & 0.0009 & 0.41 & -7.12 \\
\hline & & $\begin{array}{l}7.12+3.19 \\
\operatorname{Ln}(\mathrm{dmf})\end{array}$ & n.s. & 0.38 & 5.02 & 0.06 & 1.07 & 2.46 \\
\hline & $\operatorname{Ln}(\mathrm{C})$ & $\begin{array}{l}-3.65+0.82 \\
\mathrm{DBH}\end{array}$ & 1.5 & 0.53 & 9.14 & 0.01 & 0.81 & -0.28 \\
\hline & $\operatorname{Ln}(\mathrm{C})$ & $-0.27+0.34 \mathrm{H}_{\mathrm{tot}}$ & 1.14 & 0.85 & 46.56 & 0.0001 & 0.26 & -11.86 \\
\hline & $\operatorname{Ln}(\mathrm{C})$ & $0.05+0.41 \mathrm{H}_{\mathrm{bc}}$ & 1.21 & 0.78 & 28.3 & 0.0007 & 0.38 & -7.78 \\
\hline & $\operatorname{Ln}(\mathrm{C})$ & $0.18+5.05 \rho$ & 1.27 & 0.72 & 20.9 & 0.001 & 0.48 & -5.5 \\
\hline & & $\begin{array}{l}-1.16+15.36 \\
\mathrm{dmf}\end{array}$ & n.s. & 0.38 & 4.82 & 0.06 & 1.08 & 2.61 \\
\hline Combined model & $\operatorname{Ln}(C)$ & $\begin{array}{l}-1.5+1.92 \\
\operatorname{Ln}(\mathrm{DBH})+0.56 \\
\operatorname{Ln}\left(\mathrm{H}_{\text {tot }}\right)+0.89 \\
\operatorname{Ln}(\rho)\end{array}$ & 1.04 & 0.95 & 91.63 & 0.0002 & 0.10 & -19.49 \\
\hline Asterogyne martiana & $\operatorname{Ln}(C)$ & $\begin{array}{l}-5.21+3.27 \\
\operatorname{Ln}(\mathrm{DBH})\end{array}$ & 1.09 & 0.79 & 49.98 & $<0.0001$ & 0.18 & -23.53 \\
\hline
\end{tabular}




\begin{tabular}{|c|c|c|c|c|c|c|c|c|}
\hline & $\operatorname{Ln}(\mathrm{C})$ & $\begin{array}{l}-1.87+1.08 \\
\operatorname{Ln}\left(\mathrm{H}_{\text {tot }}\right)\end{array}$ & 1.32 & 0.36 & 7.38 & 0.01 & 0.56 & -6.61 \\
\hline & $\operatorname{Ln}(\mathrm{C})$ & $\begin{array}{l}-1.57+13.69 \\
\operatorname{Ln}(\rho)\end{array}$ & n.s. & 0.24 & 4.18 & 0.06 & 0.67 & -4.04 \\
\hline & $\operatorname{Ln}(\mathrm{C})$ & $\operatorname{Ln}(\mathrm{dmf})$ & n.s. & 0.03 & 0.44 & 0.51 & 0.86 & -0.37 \\
\hline & $\operatorname{Ln}(\mathrm{C})$ & $-5.79+1.4 \mathrm{DBH}$ & 1.12 & 0.73 & 35.56 & $<0.0001$ & 0.24 & -19.63 \\
\hline & $\operatorname{Ln}(\mathrm{C})$ & $-3.22+1.22 \mathrm{H}_{\mathrm{tot}}$ & 1.37 & 0.28 & 5.24 & 0.04 & 0.64 & -4.94 \\
\hline & $\operatorname{Ln}(\mathrm{C})$ & $-4.18+5.06 \rho$ & n.s. & 0.23 & 3.94 & 0.06 & 0.68 & -3.88 \\
\hline & $\operatorname{Ln}(\mathrm{C})$ & $-0.87-4.4 \mathrm{dmf}$ & n.s. & 0.03 & 0.4 & 0.54 & 0.86 & -0.32 \\
\hline Combined model & $\operatorname{Ln}(C)$ & $\begin{array}{l}-3.85+3 \\
\operatorname{Ln}(D B H)+1.06 \\
\operatorname{Ln}(\rho)\end{array}$ & 1.07 & 0.84 & 30.87 & $<0.0001$ & 0.16 & -25.09 \\
\hline \multirow[t]{8}{*}{ Geonoma interrupta } & $\operatorname{Ln}(\mathrm{C})$ & $\begin{array}{l}-4.39+2.96 \\
\operatorname{Ln}(\mathrm{DBH})\end{array}$ & n.s. & 0.3 & 3.41 & 0.1 & 1.96 & 8.48 \\
\hline & $\operatorname{Ln}(C)$ & $\begin{array}{l}-1.1+1.56 \\
\operatorname{Ln}\left(H_{\text {tot }}\right)\end{array}$ & 1.1 & 0.92 & 105.44 & $<0.0001$ & 0.2 & -14.48 \\
\hline & $\operatorname{Ln}(\mathrm{C})$ & $5+3.82 \operatorname{Ln}(\rho)$ & 1.4 & 0.66 & 25.51 & 0.001 & 0.66 & -2.28 \\
\hline & & $\begin{array}{l}6.1+4.88 \\
\operatorname{Ln}(\mathrm{dmf})\end{array}$ & 1.26 & 0.83 & 40.22 & 0.0002 & 0.46 & -5.92 \\
\hline & $\operatorname{Ln}(\mathrm{C})$ & $\begin{array}{l}-2.16+0.49 \\
\mathrm{DBH}\end{array}$ & n.s. & 0.33 & 4 & 0.08 & 1.86 & 7.97 \\
\hline & $\operatorname{Ln}(\mathrm{C})$ & $-1.2+0.41 \mathrm{H}_{\mathrm{tot}}$ & 1.13 & 0.91 & 83.58 & $<0.0001$ & 0.24 & -12.34 \\
\hline & $\operatorname{Ln}(\mathrm{C})$ & $-3.68+12.8 \rho$ & 1.33 & 0.79 & 30.88 & 0.0005 & 0.57 & -3.78 \\
\hline & $\operatorname{Ln}(\mathrm{C})$ & $\begin{array}{l}-4.28+14.49 \\
\mathrm{dmf}\end{array}$ & 1.28 & 0.82 & 37.41 & 0.0003 & 0.49 & -5.32 \\
\hline
\end{tabular}


Table 3. General allometric models to estimate total carbon content $(\mathrm{C} ; \mathrm{kg})$ based on 7 species of neotropical palms. DBH: Diameter at breast height $(\mathrm{cm}), \mathrm{H}_{\mathrm{tot}}$ : Total height $(\mathrm{m})$, dmf: dry mass fracion, $\rho$ : density of the sclerotized tissue $\left(\mathrm{g} / \mathrm{cm}^{3}\right)$. CF: Correction factor recommended by Sprugel (1983). MSE: Mean square of error. AIC: Akaike's information criteria. Ln: Natural logarithm. The most efficient model is highlighted in bold-faced.

\begin{tabular}{|c|c|c|c|c|c|c|c|}
\hline & Model & $\mathrm{CF}$ & $\mathbf{R}^{2}$ & $\mathbf{F}$ & $\mathbf{P}$ & MSE & AIC \\
\hline $\operatorname{Ln}(\mathrm{C})$ & $-1.46+0.28 \mathrm{DBH}$ & 1.71 & 0.66 & 165.2 & $<0.0001$ & 1.07 & 8.26 \\
\hline $\operatorname{Ln}(C)$ & $-1.46+0.41 \mathrm{H}_{\mathrm{tot}}$ & 1.36 & 0.80 & 350.74 & $<0.0001$ & 0.61 & -40.0 \\
\hline $\operatorname{Ln}(\mathrm{C}$ & $1.27-3.6 \mathrm{dmf}$ & n.s. & 0.04 & 3.81 & 0.054 & 3.02 & 98.36 \\
\hline $\operatorname{Ln}(C)$ & $0.52-0.33 \rho$ & n.s. & 0.0006 & 0.05 & 0.82 & 3.16 & 102.14 \\
\hline $\operatorname{Ln}(C)$ & $\begin{array}{l}-3.26+2.25 \\
\operatorname{Ln}(\mathrm{DBH})\end{array}$ & 1.39 & 0.79 & 323.8 & $<0.0001$ & 0.66 & -34.30 \\
\hline $\operatorname{Ln}(C)$ & $-1.2+1.54 \mathrm{Ln}\left(\mathrm{H}_{\mathrm{tot}}\right)$ & 1.36 & 0.80 & 352.3 & $<0.0001$ & 0.61 & -40.31 \\
\hline $\operatorname{Ln}(C)$ & $-1.33-1.14 \operatorname{Ln}(\mathrm{dmf})$ & 4.3 & 0.08 & 7.11 & 0.009 & 2.91 & 95.19 \\
\hline $\operatorname{Ln}(C)$ & $-0.06-0.35 \operatorname{Ln}(\rho)$ & n.s. & 0.09 & 0.8 & 0.37 & 3.13 & 101.36 \\
\hline $\operatorname{Ln}(C)$ & $\begin{array}{l}-1.4+1.4 \operatorname{Ln}(\mathrm{DBH})+ \\
0.94 \operatorname{Ln}\left(\mathrm{H}_{\text {tot }}\right)+0.97 \\
\operatorname{Ln}(\operatorname{dmf})\end{array}$ & 1.12 & 0.92 & 486.02 & $<0.0001$ & 0.34 & -89.62 \\
\hline
\end{tabular}


Table 4. General allometric models to estimate above-ground carbon content (AGC; kg) based on 7 species of neotropical palms. DBH: Diameter at breast height $(\mathrm{cm}), \mathrm{H}_{\text {tot: }}$ : Total height $(\mathrm{m})$, dmf: dry mass fraction, $\rho$ : density of the sclerotized tissue $\left(\mathrm{g} / \mathrm{cm}^{3}\right) . \mathrm{CF}$ : Correction factor recommended by Sprugel (1983). MSE: Mean square of error. AIC: Akaike's information criteria. Ln: Natural logarithm. The most efficient model is highlighted in bold-faced.

\begin{tabular}{|c|c|c|c|c|c|c|c|}
\hline & Model & $\mathbf{C F}$ & $\mathbf{R}^{2}$ & $\mathbf{F}$ & $\mathbf{P}$ & MSE & AIC \\
\hline $\operatorname{Ln}(\mathrm{AGC})$ & $-1.72+0.28 \mathrm{DBH}$ & 1.7 & 0.66 & 161.41 & $<0.0001$ & 1.06 & 7.18 \\
\hline $\operatorname{Ln}(\mathrm{AGC})$ & $-1.72+0.41 \mathrm{H}_{\mathrm{tot}}$ & 1.4 & 0.79 & 321.05 & $<0.0001$ & 0.64 & -36.27 \\
\hline $\operatorname{Ln}(\mathrm{AGC})$ & $0.89-3.24 \mathrm{dmf}$ & n.s. & 0.04 & 3.14 & 0.08 & 2.96 & 96.62 \\
\hline $\operatorname{Ln}(\mathrm{AGC})$ & $0.14-0.06 \rho$ & n.s. & 0 & 0.002 & 0.96 & 3.08 & 99.78 \\
\hline $\operatorname{Ln}(\mathrm{AGC})$ & $-3.48+2.2 \operatorname{Ln}(\mathrm{DBH})$ & 1.4 & 0.68 & 300.58 & $<0.0001$ & 0.68 & -31.77 \\
\hline $\operatorname{Ln}(\mathrm{AGC})$ & $-1.45+1.48 \mathrm{Ln}\left(\mathrm{H}_{\mathrm{tot}}\right)$ & 1.41 & 0.78 & 292.76 & $<0.0001$ & 0.69 & -29.98 \\
\hline $\operatorname{Ln}(\mathrm{AGC})$ & $-1.46-1.04 \mathrm{Ln}(\mathrm{dmf})$ & 4.21 & 0.06 & 5.95 & 0.01 & 2.88 & 93.89 \\
\hline $\operatorname{Ln}(\mathrm{AGC})$ & $-0.22-0.26 \operatorname{Ln}(\rho)$ & n.s. & 0.005 & 0.44 & 0.51 & 3.06 & 99.34 \\
\hline $\operatorname{Ln}(\mathbf{A G C})$ & $\begin{array}{l}-1.59+1.46 \mathrm{Ln} \\
(\mathrm{DBH})+0.88 \\
\operatorname{Ln}\left(\mathrm{H}_{\text {tot }}\right)+1.04 \\
\operatorname{Ln}(\mathrm{dmf})\end{array}$ & 1.14 & 0.91 & 284.54 & $<0.0001$ & 0.28 & -107.05 \\
\hline
\end{tabular}


Table 5. Coefficients of the eigenvectors of the first three first principal components calculated from the Ln-transformed values of nine morphological variables describing the morphological structure of 7 palm species from different strata in the Caribbean slope of Costa Rica.

\begin{tabular}{|c|c|c|c|}
\hline Variable & $\begin{array}{c}\text { PC1 (eigenvalue }=4) \\
44.40 \%\end{array}$ & $\begin{array}{c}\text { PC2 }(\text { eigenvalue } \\
17.74 \%\end{array}$ & $\begin{array}{c}\text { PC3 }(\text { eigenvalue }=1.6) \\
15.73 \%\end{array}$ \\
\hline $\begin{array}{l}\text { Ln root:shoot } \\
\text { biomass }\end{array}$ & -0.04 & -0.41 & 0.61 \\
\hline $\begin{array}{l}\text { Ln root:shoot } \\
\text { carbon }\end{array}$ & 0.11 & -0.13 & 0.66 \\
\hline Ln tissue density & -0.21 & 0.56 & 0.28 \\
\hline Ln DBH & 0.46 & $-0-08$ & 0.04 \\
\hline $\mathrm{Ln} \mathrm{H}_{\text {tot }}$ & 0.47 & 0.23 & 0.06 \\
\hline Ln dmf & -0.30 & 0.40 & 0.28 \\
\hline Ln total Carbon & 0.44 & 0.18 & 0.14 \\
\hline Ln slenderness & 0.26 & 0.48 & 0.05 \\
\hline Ln leaf area & 0.38 & -0.12 & -0.06 \\
\hline
\end{tabular}


Figure 1. Tissue density (A), slenderness ratio (B), dmf (C), root:shoot based on biomass (D), and root:shoot based on carbon content (E) according to palm species. Different letters next to boxplots show significant differences using Tukey HSD test.

Figure 2. Tissue density according to palm species and position along the stem in 7 species of palms in the Caribbean lowlands of Costa Rica. Species abbreviations follow Table 1. The position along the stem went from the stem apex to the base of the stem.

Figure 3. Predicted vs. observed values and residuals of the $\mathrm{Ln}$ of AGC in $\mathrm{kg}$ following the pantropical model of Chave et al. (2014), Goodman et al. (2013)'s model, and the general palm model proposed in this study (Table 3).

Figure 4. Pearson correlation matrix of morphological traits in 7 species of palms in Costa Rica. Trait abbreviations follow Table 1.

Figure 5. Ordination of species per forest strata in the space determined by the first two principal components accounting for $62.14 \%$ of the variation in 9 morphological characters defined for 7 species of tropical palms (red oval: canopy palms Iriartea deltoidea and Socratea exorrhiza, green oval: subcanopy palm Euterpe precatoria, and blue oval: understory palms Asterogyne martiana, Prestoea decurrens, Chamaedorea tepejilote and Geonoma interrupta). 
Figure 1
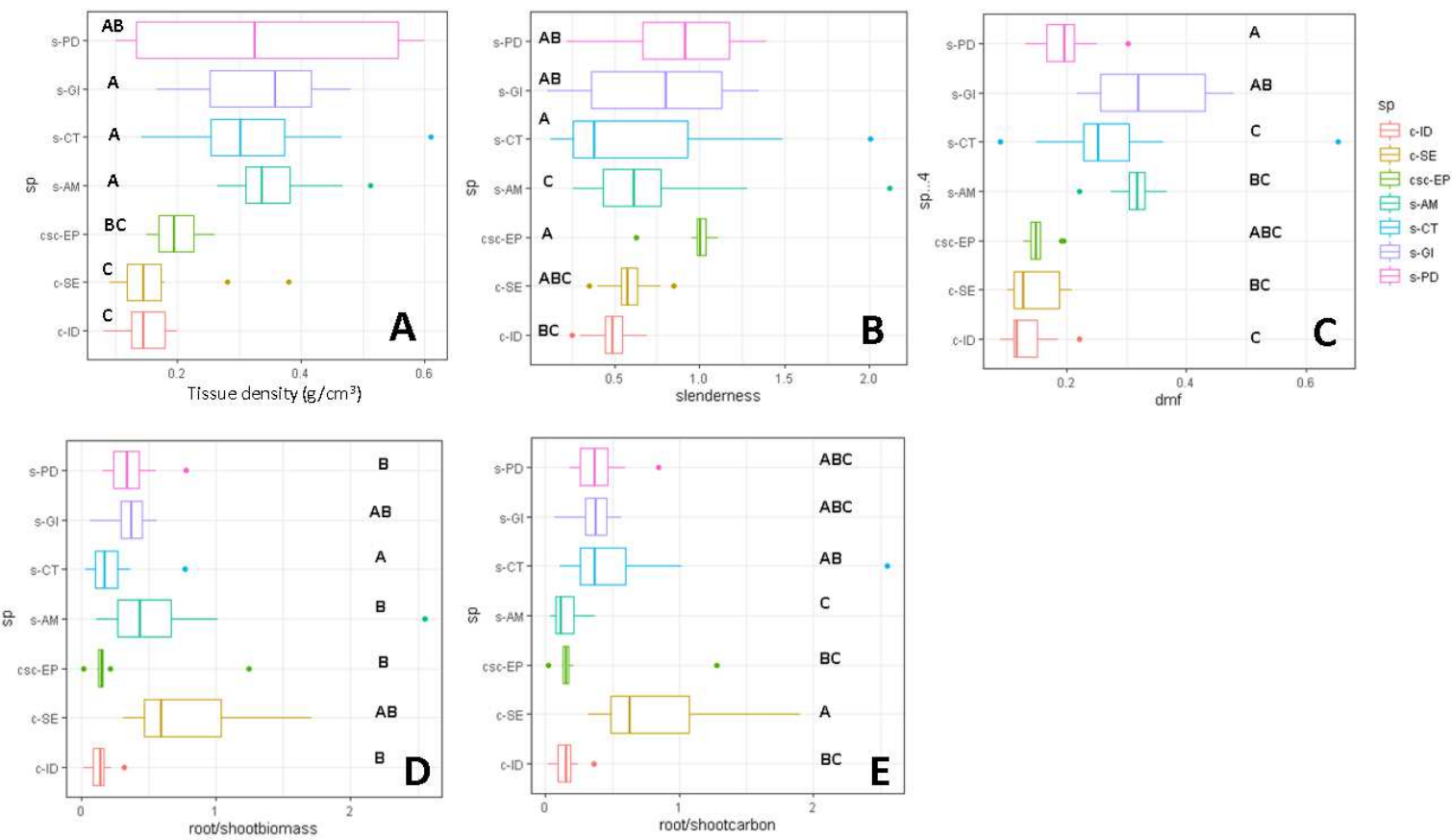
Figure 2
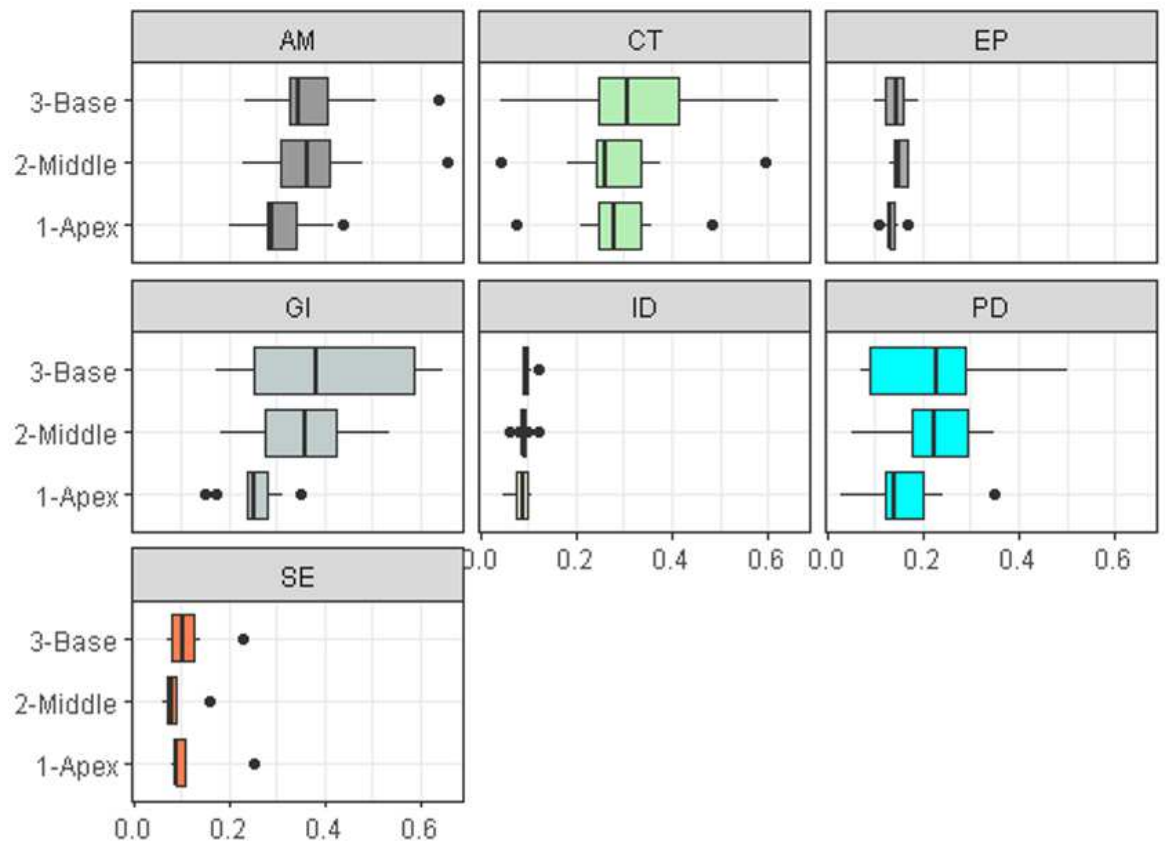

Tissue density $\left(\mathrm{g} / \mathrm{cm}^{3}\right)$ 
Figure 3
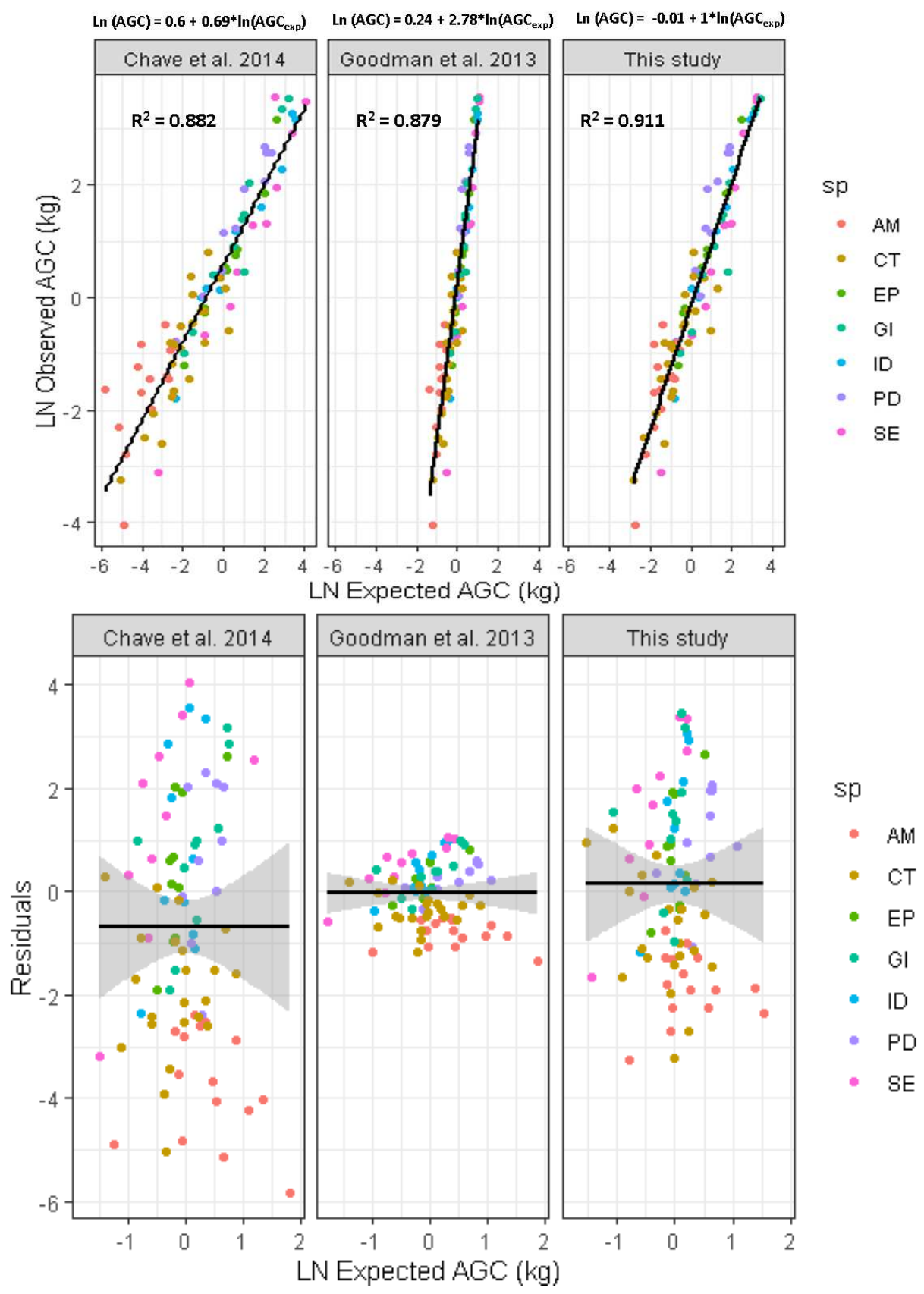
Figure 4

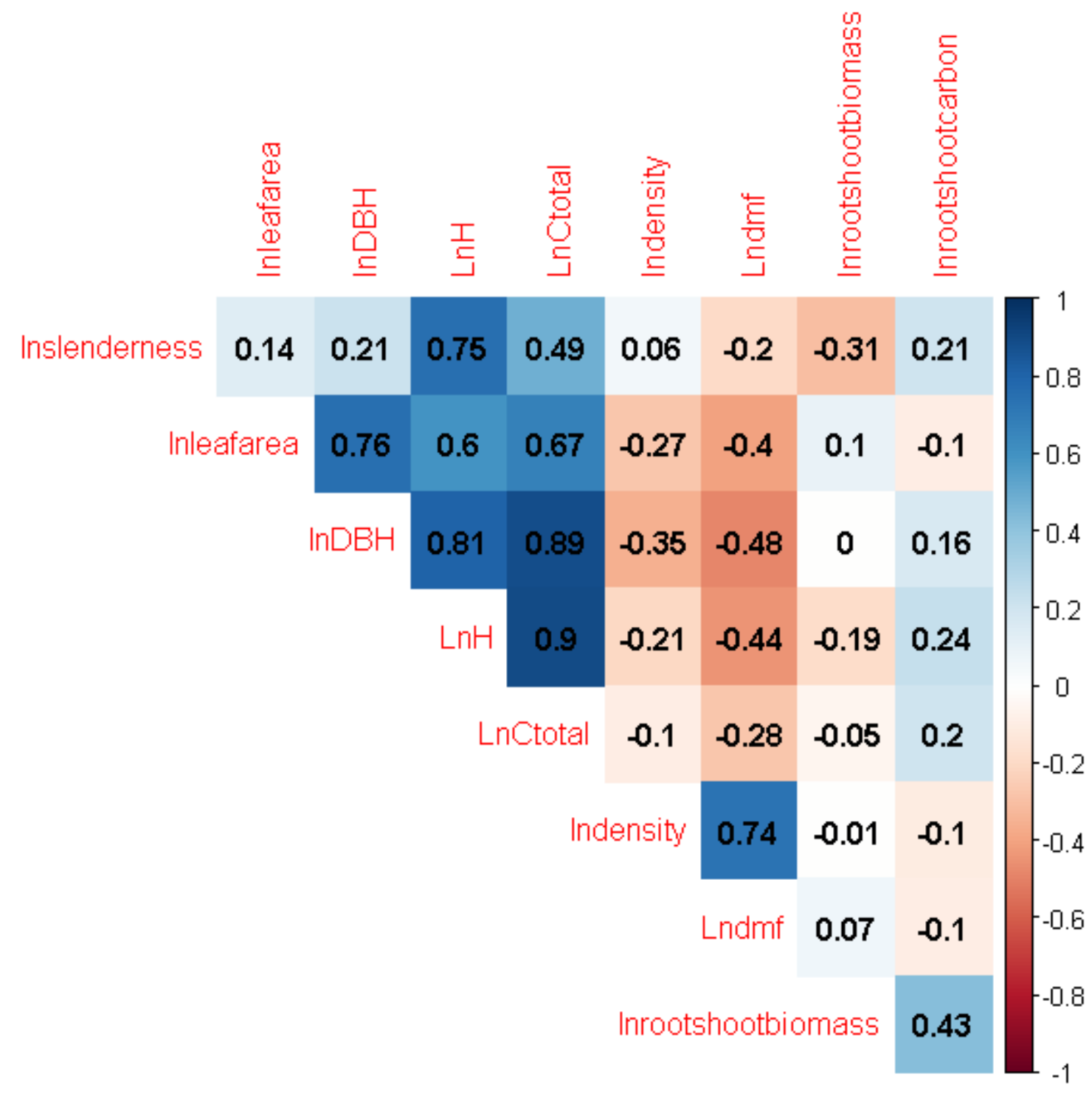


Figure 5

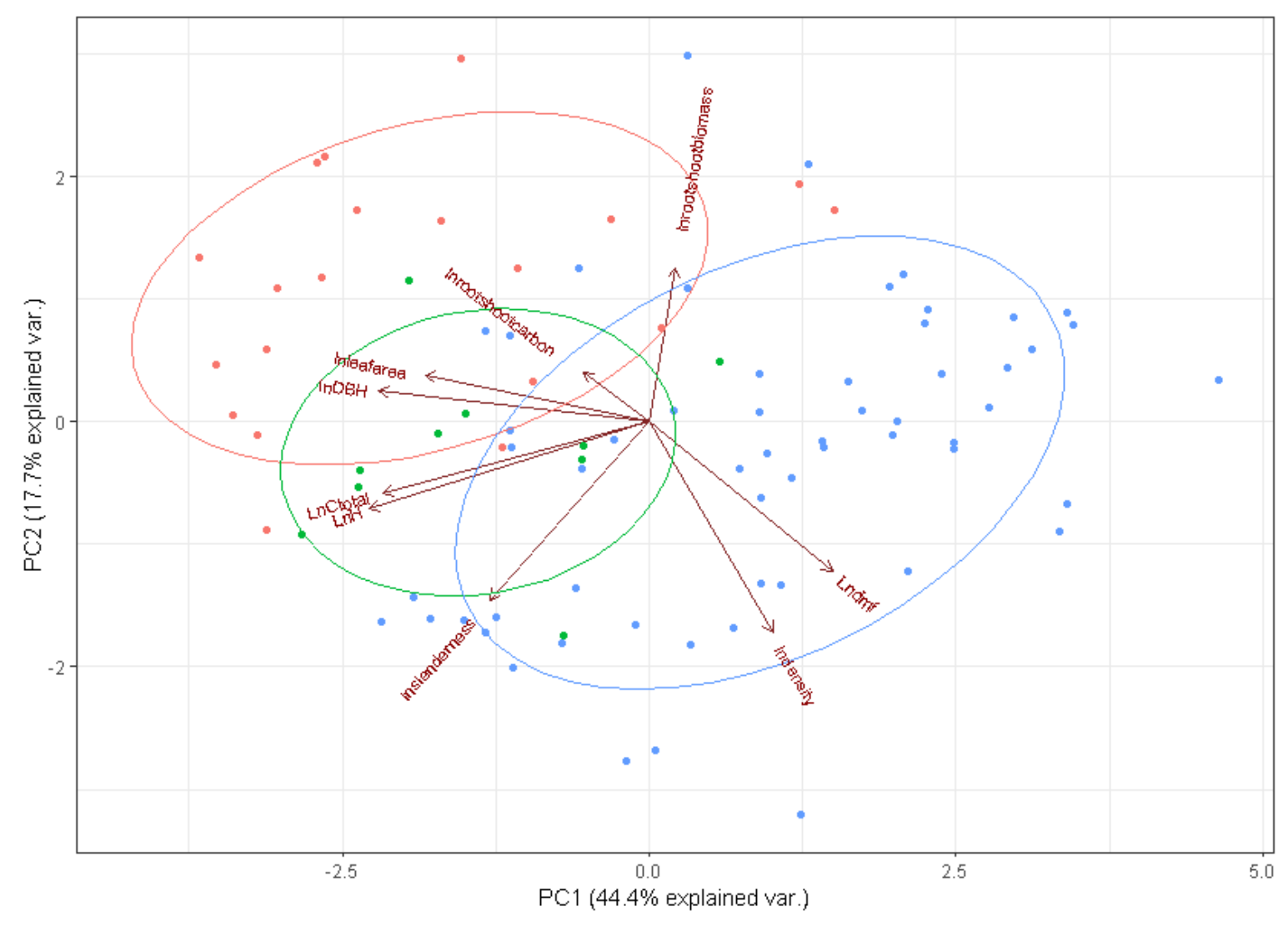

